\title{
A Imaginação Moral de J. R. R. Tolkien e os Conceitos de Liberdade na Trilogia O Senhor dos Anéis*
}

\author{
Alex Catharino**
}

\begin{abstract}
Resumo: $\mathrm{O}$ artigo analisa a questão da Liberdade na saga $O$ Senhor dos Anéis de J. R. R. Tolkien, tanto no plano filosófico quanto nos aspectos praxeológicos, a partir do conceito de Imaginação Moral de Russell Kirk e segundo algumas perspectivas teóricas da Escola Austríaca de Economia, enfatizando, também, as principais características da obra literária tolkieniana.
\end{abstract}

Palavras-chave: Crítica Literária, Filosofia da Cultura, Ética, Liberdade, J. R. R. Tolkien, O Senhor dos Anéis.

\section{The Moral Imagination of J.R.R. Tolkien and the Concepts of Freedom in the Trilogy The Lord of the Rings}

\begin{abstract}
The article analyzes the problem of Freedom of J. R. R. Tolkien's saga The Lord of the Rings, both in Philosophy and in their praxeological aspects from Russell Kirk's concept of Moral Imagination and according to some Austrian School of Economics theoretical perspectives, as well as emphasizing the main characteristics of the Tolkienian literary work.
\end{abstract}

Keywords: Literary Criticism, Philosophy of Culture, Ethics, Freedom, J. R. R. Tolkien, The Lord of the Rings.

Classificação JEL: B53, Z1

\footnotetext{
* O presente ensaio é uma versão revista e ampliada da conferência A Imaginação Moral de J. R. R. Tolkien e a defesa da Liberdade na trilogia $\boldsymbol{O}$ Senhor dos Anéis apresentada, em 1 de setembro de 2012, como parte da programação da I Conferência Nacional dos Estudantes Pela Liberdade (EPL), realizada, entre 1 e 2 de setembro de 2012, em Belo Horizonte, MG.

** Alex Catharino é vice-presidente executivo do Centro Interdisciplinar de Ética e Economia Personalista (CIEEP), editor assistente dos periódicos COMMUNIO: Revista Internacional de Teologia e Cultura e The Chesterton Review Suplemento Especial em Português, gerente editorial do periódico MISES: Revista Interdisciplinar de Filosofia, Direito e Economia, pesquisador residente do Russell Kirk Center for Cultural Renewal, em Mecosta, Michigan, EUA, e pesquisador afiliado do Acton Institute for the Study of Religion and Liberty, em Grand Rapids, Michigan, EUA. Cursou a Faculdade de História na Universidade Federal do Rio de Janeiro (UFRJ) e fez estudos nas áreas de História, Arqueologia, Paleografia, Literatura, Filosofia, Teologia, Economia e Ciência Política em diferentes instituições no Brasil, EUA, Portugal, Itália, Argentina, Colômbia e Uruguai. Foi visiting fellow da Atlas Economic Research Foundation, em Washington, D.C., EUA. É coautor das obras Ensaios sobre Liberdade e Prosperidade (UNA Editoria, 2001) e Dicionário de Filosofia Política (Editora UNISINOS, 2010), além de autor de artigos em diferentes periódicos acadêmicos e dos estudos introdutórios para a edição brasileira dos livros $A$ Era de T. $S$. Eliot: A Imaginação Moral do Século XX (É Realizações, 2011) e A Política da Prudência (É Realizações, 2013), ambos de Russell Kirk.

E-mail: alex@mises.org.br
} 
Décadas antes do lançamento da mundialmente famosa e bem-sucedida trilogia de filmes dirigida pelo cineasta Peter Jackson, entre 2001 e 2003, a saga The Lord of the Rings [O Senhor dos Anéis], do filólogo e literato britânico John Ronald Reuel Tolkien (1892-1973), já havia sido considerada uma das obras literárias mais importantes do século XX. O próprio Tolkien não considerva $O$ Senhor dos Anéis como uma trilogia, mas como uma única longa obra, que, por razões editoriais, foi dividida nos volumes The Fellowship of the Ring [A Sociedade do Anel]', The Two Towers [As Duas Torres] ${ }^{2}$ e The Return of the King [O Retorno do Rei] ${ }^{3}$, publicados, respectivamente, em 29 de julho de 1954, 11 de novembro de 1954, e, 20 de outubro de 1955.

Desde o lançamento, O Senhor dos Anéis vendeu mais de cento e cinquenta milhões de exemplares em língua inglesa, o que o torna a segunda obra literária moderna mais bem-sucedida do mundo, ficando atrás apenas do livro A Tale of Two Cities [Um Conto de Duas Cidades], de Charles Dickens (18121870), que, publicado originalmente em 1859, já teve mais de duzentos milhões de cópias comercializadas. A beleza estilística fez que O Senhor dos Anéis fosse comparado em importância artística, por diferentes críticos, aos poemas épicos Ilíada e Odisséia, de Homero, Eneida, de Virgílio (70-19 a.C.), A Divina Comédia, de Dante Alighieri (1265-1321), e O Paraíso Perdido, de John Milton (1608-1674), à tragédia Hamlet de William Shakespeare (1564-1616), à opera Flauta Mágica (K 620) e ao Réquiem (K 626), de Wolfgang Amadeus Mozart (17561791), à Nona Sinfonia (Op. 125) de Ludwig van Beethoven (1770-1827) e, até mesmo, ao

1 TOLKIEN, J. R. R. O Senhor dos Anéis: A Sociedade do Anel. Trad. Lenita Maria Rímoli Esteves e Almiro Pisetta. São Paulo: Martins Fontes, 2001.

${ }^{2}$ Idem. O Senhor dos Anéis: As Duas Torres. Trad. Lenita Maria Rímoli Esteves e Almiro Pisetta. São Paulo: Martins Fontes, 2001.

${ }^{3}$ Idem. O Senhor dos Anéis: O Retorno do Rei. Trad. Lenita Maria Rímoli Esteves e Almiro Pisetta. São Paulo: Martins Fontes, 2001. romance Ulisses de James Joyce (1882-1941). A obra de Tolkien foi elogiada por vários literatos renomados, como C. S. Lewis (1898$1963)^{4}$, W. H. Auden (1907-1973)5, Edmund Fuller (1914-2001) ${ }^{6}$, Russell Kirk (1918-1994), John Gardner (1933-1982)8 e Marion Zimmer Bradley (1930-1999)', Ursula K. Le Guin ${ }^{10}$ e George R. R. Martin ${ }^{11}$, dentre outros. O impacto de O Senhor dos Anéis na cultura popular contemporânea foi imenso, servindo como modelo para a maioria das obras literárias do gênero de fantasia mitopoética ${ }^{12}$, dentre as quais se destacam, além da própria criação de

${ }^{4}$ LEWIS, C.S. The Dethronement of Power. In: ISAACS, Neil D. \& ZIMBARDO, Rose A. (Ed.). Tolkien and the Critics: Essays on J. R. R. Tolkien's The Lord of the Rings. Notre Dame: University of Notre Dame Press, 1970. p. 12-16.

5 AUDEN, W. H. The Quest Hero. In: ISAACS \& ZIMBARDO (Ed.). Tolkien and the Critics. p. 40-61.

${ }^{6}$ FULLER, Edmund. The Lord of the Hobbits: J. R. R. In: ISAACS \& ZIMBARDO (Ed.). Tolkien and the Critics. p. 17-39.

7 KIRK, Russell. Tolkien e a Verdade da Fantasia. Trad. e notas Alex Catharino. COMMUNIO: Revista Internacional de Teologia e Cultura, v. 27, n. 3, p. 78386. Jul.-Set. 2008.

${ }^{8}$ GARDNER, John. On Moral Fiction. Intr. Lore Segal. New York: Basic Books, 2000. p. 194-95.

${ }^{9}$ BRADLEY, Marion Zimmer. Men, Halflings, and Hero Worship. In: ISAACS \& ZIMBARDO (Ed.). Tolkien and the Critics. p. 109-27.

${ }^{10}$ LE GUIN, Ursula K. Rhythmic Pattern in The Lord of the Rings. In: HABER, Karen (Ed.). Meditation on Middle-Earth. New York: St. Martin's, 2001. p. 101-16.

11 MARTIN, George R. R. Introduction. In: HABER. Meditation on Middle-Earth. p. 1-6.

${ }^{12}$ A principal referência sobre o genêro é o seguinte ensaio: TOLKIEN, J. R. R. Sobre Histórias de Fadas. In: Sobre Histórias de Fadas. Trad. Ronald Kyrmse. São Paulo: Conrad, 2006. p. 9-89. Uma análise detalhada e uma tentativa de definição da Fantasia Mitopoética aparece em: WAGGONER, Diana. The Hills of Faraday: A Guide to Fantasy. New York: Atheneum, 1978. Em língua portuguesa, ver: OZIEWICZ, Marek. Prolegômenos à Fantasia Mitopoética. Trad. Márcia Xavier de Brito. COMMUNIO: Revista Internacional de Teologia e Cultura, v. 28, n. 1, p. 121-49. Jan.-Mar. 2009. 
Tolkien, a série Harry Potter de J. K. Rowling ${ }^{13}$, e os escritos dos já citados C. S. Lewis, George R. R. Martin e Ursula K. Le Guin. O Senhor dos Anéis, também, foi uma importante influência para a saga de filmes Star Wars [Guerra nas Estrelas], do cineasta norte-americano George Lucas $^{14}$, para as criações artísticas de diversos ilustradores, para os jogos de RPG [Role-Playing Game] e para os trabalhos musicais de diferentes bandas de rock progressivo ou de heavy metal, como Led Zeppelin, Rush, Marillion, Helloween, Megadeth e Mostly Autumn, bem como, para as composições do tecladista Rick Wakeman e da cantora Enya.

A importância de O Senhor dos Anéis, no entanto, não se limita ao reconhecimento dos padrões literários pela crítica especializada, ao sucesso comercial e à influência cultural, pois a criação de J. R. R. Tolkien, também, tem sido objeto de inúmeros estudos acadêmicos nas áreas de Literatura, Filosofia e Teologia ${ }^{15}$, por conta do rico simbolismo presente na saga que retrata importantes questões relativas aos juízos morais e à ação humana. Todos esses fatores fizeram Tolkien ser denominado pelo professor Tom Shippey de "o autor do século"16.

${ }^{13}$ Em diferentes entrevistas a escritora J. K. Rowling expressou a admiração pela obra de J. R. R. Tolkien. Sobre a a influência de $O$ Senhor dos Anéis nos escritos da autoura da saga Harry Potter, ver: SMITH, Sean. J. K. Rowling: A Biography. London: Michael O'Mara Books, 2003. p. 90-92, 108, 148, 201.

${ }^{14}$ Sobre a influência de O Senhor dos Anéis na saga Guerra nas Estrelas, bem como uma análise da imaginação moral veiculada pela série de filmes de George Lucas, ver: CATHARINO, Alex. A Imaginação Moral em Star Wars. COMMUNIO: Revista Internacional de Teologia e Cultura, v. 28, n. 1, p. 221-52. Jan.-Mar. 2009.

15 A relação quase completa de todos os ensaios e livros sobre Tolkien, publicados até 1980, aparece em: WEST, Richard C. Tolkien Criticism: An Annotated Checklist. Kent: Kent State University Press, Rev. Ed., 1981. p. 13-142. Uma relação bibliográfica parcial e mais atualizada dos estudos sobre O Senhor dos Anéis pode ser encontrada em: BIRZER, Bradley J. J. R. R. Tolkien's Sanctifying Myth: Understanding Middleearth. Pref. Joseph Pearce. Wilmington: ISI Books, 2002. p. 177-203.

16 SHIPPEY, Tom. J. R. R. Tolkien: Author of the Century. New York: Houghton Mifflin Company, 2000.
A partir do conceito de imaginação moral, na definição de Russell Kirk, apresentaremos as principais características da obra literária tolkieniana e enfatizaremos a maneira como as diferentes formas de liberdade são apresentadas na narrativa de $O$ Senhor dos Anéis, criando algumas analogias com as reflexões da Escola Austríaca de Economia sobre as noções de liberdade, tal como apresentadas nos escritos de Ludwig von Mises (1881-1973), Friedrich August von Hayek (1899-1992) e Murray N. Rothbard (1926-1995).

\section{I - O Conceito KirkeAno de IMAGINAÇÃo MoraL}

Na obra Poética, Aristóteles (384-322 a.C.) argumentou que não faz parte do ofício do literato "narrar o que aconteceu"; a função do artista é a "de representar o que poderia acontecer, quer dizer: o que é possível segundo a verossimilhança e a necessidade" (1451a / IX, 50). As diferentes expressões literárias, seja comédia ou tragédia, apresentam "algo de mais filosófico e mais sério que a história", visto que a história trata do particular, ao passo que a literatura volta-se ao universal. As belas letras, por tratarem do universal, atribuem "a um indivíduo de determinada natureza pensamentos e ações que, por liame de necessidade e verossimilhança, convêm a tal natureza" (1451b / IX, 50) ${ }^{17}$.

Além dos padrões estéticos inerentes à própria criação artística, a boa literatura caracteriza-se pelo compromisso com uma forma de imaginação disciplinada. O filósofo e crítico literário Irving Babbitt (1865-1933) afimou que "a verdadeira visão da imaginação disciplinada é indispensável caso se queira lucrar pela experiência", no entanto, essa é "uma tarefa que se torna crescentemente difícil, dependendo do envolvimento na própria experiência que se tem, ou na de contemporâneos, ou nas dos passados remoto

\footnotetext{
${ }^{17}$ ARISTÓTELES. Poética. Trad. Eudoro de Souza. São Paulo: Abril Cultural, 1973. (Coleção "Os Pensadores", Volume IV: Aristóteles).
} 
e próximo"18. A imaginação moral por ser um "poder de percepção ética que atravessa as barreiras da experiência individual e de eventos momentâneos" e aspira "à apreensão da ordem correta na alma e da ordem correta na comunidade política", tal como definida por Russell Kirk, é um dos melhores meios disponíveis para informar "sobre a dignidade da natureza humana"19.

A expressão "imaginação moral" foi utilizada nos últimos anos por diferentes autores para descrever aspectos distintos da moralidade, alguns deles, até mesmo, contraditórios. Dentre as diferentes concepções de imaginação moral, a que mais se adequa à narratologia e aos fundamentos teóricos defendidos por J. R. R. Tolkien são as reflexões apresentadas por Russell Kirk e por seus discípulos. Nessa perspectiva, a imaginação moral pode ser entendida como parte de um processo pessoal de descoberta da direção e do propósito da vida, "ao criar metáforas das experiências recordadas e ao empregar tais metáforas para sugerir úteis correlações com a experiência presente", transcendendo, assim, "a necessidade natural", pois, não é um mero instinto, sendo, ao mesmo tempo, "atributo e expressão de liberdade, paixão e razão" $0^{\prime 20}$. As normas apresentadas pela imaginação moral são "inferidas dos séculos de experiência humana", sendo "novamente expressas de uma era para a outra"21. A noção de imaginação moral pode ser entendida como o meio que possibilita "discernir o que a pessoa humana pode ser, apreendendo, por ale-

\footnotetext{
${ }^{18}$ BABBITT, Irving. Democracia e Liderança. Pref. Russell Kirk, trad. Joubert de Oliveira Brízida. Rio de Janeiro: Topbooks, 2003. p. 169.

${ }^{19}$ KIRK, Russell. A Imaginação Moral. Trad. Gustavo Santos, notas Alex Catharino. COMMUNIO: Revista Internacional de Teologia e Cultura, v. 28, n. 1, p. 10319. Jan.-Mar. 2009, p. 104.

${ }^{20}$ GUROIAN, Vigen. A Imaginação Moral e os Contos de Fadas. Trad. e notas Márcia Xavier de Brito. COMMUNIO: Revista Internacional de Teologia e Cultura, v. 27, n. 1, p. 185-202, Jan.-Mar. 2008, p. 190.

${ }^{21}$ KIRK, Russell. A Era de T. S. Eliot: A Imaginação Moral do Século XX. Apr. Alex Catharino, intr. Benjamin G. Lockerd Jr., trad. Márcia Xavier de Brito. São Paulo: É Realizações, 2011. p. 140.
}

gorias, a correta ordem da alma e a justa ordem da sociedade"22. Nessa perspectiva, "quando a imaginação moral se enriquece, as pessoas se percebem capazes de grandes coisas", no entanto, o empobrecimento dessa percepção ética impossibita a ação com eficácia e a "própria sobrevivência, a despeito da abundância de recursos materiais" ${ }^{\prime 23}$.

O termo "imaginação moral" foi criado originalmente por Edmund Burke (1729-1797) como uma metáfora para descrever a maneira como os revolucionários franceses, pautados em falácias ideológicas, estavam promovendo a destruição dos costumes civilizatórios tradicionais que durante gerações foi sustentado pelo espírito religioso e pelo sentimento de cavalheirismo. Na obra Reflections on the Revolution in France [Reflexões sobre a Revolução em França], publicada pela primeira vez em 1790, Burke afirmou:

Agora, porém, tudo irá mudar. Todas as agradáveis ilusões, que tornaram o poder gentil e a obediência liberal, que harmonizaram os diferentes tons da vida e que, por branda assimilação, incorporaram na política os sentimentos que embelezam e suavizam as relações particulares, deverão ser dissolvidas pela conquista recente da luz e da razão. Toda a roupagem decente da vida deverá ser rudemente rasgada. Todas as ideias decorrentes disso, guarnecidas pelo guarda-roupa da imaginação moral, que vem do coração e que o entendimento ratifica como necessárias para dissimular os defeitos de nossa natureza nua e elevá-la à dignidade de nossa estima, deverão ser encostadas como moda ridícula, absurda e antiquada ${ }^{24}$.

${ }^{22}$ CATHARINO, Alex. A vida e a imaginação de Russell Kirk. In: KIRK, Russell. A Era de T. S. Eliot: A Imaginação Moral do Século XX. p. 11-104. Cit. p. 82.

${ }^{23}$ KIRK, Russell. A Arte Normativa e os Vícios Modernos. Trad. Gustavo Santos, notas Alex Catharino. COMMUNIO: Revista Internacional de Teologia e Cultura, v. 27, n. 4, p. 993-1017, Out.-Dez. 2008, p. 993.

${ }^{24}$ BURKE, Edmund. Reflexões sobre a Revolução em França. Intr. Connor Cruise O'Brien, trad. Renato de Assumpção Faria, Denis Fontes de Souza Pinto e Carmen Lídia Richter Ribeiro Moura. Brasília: Editora Universidade de Brasília, 1982. p. 101. 
A expressão cunhada por Burke tomou dimensões mais amplas nas reflexões de Kirk, que, ao relacionar o insight burkeano com algumas ideias de outros pensadores, desenvolveu um novo conceito, segundo o qual a imaginação moral é entendida ao mesmo tempo como a "capacidade distintamente humana de conceber a pessoa como um ser moral" e como o processo de criação de metáforas pelo eu a partir de experiências captadas pelos sentidos e guardadas na mente; posteriormente, tais metáforas são utilizadas para definir e julgar os padrões éticos em realidades concretas $^{25}$. Em linhas gerais o conceito kirkeano de imaginação moral se assemelha em muitos aspectos à noção descrita como Tao por C. S. Lewis, no livro A Abolição do Homem, que são os princípios expressos pela Lei Natural, denominados também como "moral tradicional, primeiros princípios da razão prática ou primeiros lugares-comuns" 26 .

Tanto as visões empiristas quanto as racionalistas, que tentam derivar as verdades éticas dos raciocínios abstratos ou das análises factuais, foram descartadas por Kirk, pois, ao entender que o sustentáculo teórico das modernas ideologias são os desvios da razão metódica, buscou um fundamento gnosiológico mais amplo para o conceito de imaginação moral, rejeitando, assim, uma base meramente racional, seja ela platônica, aristotélica, tomista, nominalista, cartesiana ou kantiana. Na perspectiva kirkeana, "o que chamamos de 'imaginação moral' tem relação com o 'sentido ilativo'"'27. A noção de sentido ilativo, por sua vez, foi desenvolvida por John Henry Newman (1801-1890), que a definiu como "a faculdade raciocinante, enquanto exercida por mentes dotadas, educadas ou diversamente preparadas",

25 CATHARINO, Alex. Russell Kirk (1918-1994). In: BARRETO, Vicente \& CULLETON, Alfredo (Eds.). Dicionário de Filosofia Política. São Leopoldo: UNISINOS, 2010. p. 289-293. Cit. p. 292.

${ }^{26}$ LEWIS, C. S. A Abolição do Homem. Trad. Remo Mannarino Filho. São Paulo: Martins Fontes, 2005. p. 12.

${ }^{27}$ KIRK. A Era de T. S. Eliot. p. 184. cuja função se apresenta "no início, no meio e no termo de toda discussão verbal e de toda a indagação, e em cada passo do processo" 28 . De forma sintética, Kirk apresentou o conceito newmaniano de sentido ilativo como um "produto combinado da intuição, do instinto, da imaginação e da longa e complexa experiência" ${ }^{\prime 29}$. Fundada em tal noção gnosiológica, a imaginação moral pode ser entendida como um processo metafórico que ajuda a formar a consciência ética do indivíduo, ao oferecer por mitos, fábulas, alegorias e parábolas a normatividade dos valores e costumes testados historicamente pela tradição do senso comum, além de alertar para os riscos da arrogância racionalista, que tenta erigir uma nova ordem social a partir dos caprichos humanos.

A concepção filosófica de sentido ilativo foi enriquecida por Russell Kirk com a noção de "democracia dos mortos" do escritor britânico G. K. Chesterton (1974-1936). Tal noção chestertoniana foi apresentada, no terceiro capítulo do livro Orthodoxy [Ortodoxia], lançado originalmente em 1908, com as seguintes palavras:

Nunca pude entender onde os homens foram buscar a ideia de que a democracia se opõe, de certo modo, à tradição. É evidente que a tradição é somente a democracia projetada através dos tempos. É acreditar no consenso de vozes humanas, em vez de acreditar em qualquer documento arbitrário ou isolado. [...] Se damos tanta importância à opinião dos homens comuns quando se trata de assuntos cotidianos, não podemos desprezar essa mesma opinião quando se trata da história e da fábula. A tradição pode ser definida como uma extensão do direito de voto, pois significa, apenas, que concedemos o voto às mais obscuras de todas as classes, ou seja, a dos nossos antepassados. É a democracia dos mortos. A tradição se recusa a submeter-se à pequena e arrogante

28 NEWMAN, John Henry. Ensaio a Favor de uma Gramática do Assentimento. Trad. e apr. Artur Morão. Lisboa: Assírio \& Alvim, 2005. p. 355.

${ }^{29}$ KIRK, Russell. The Conservative Mind: From Burke to Eliot. Pref. Henry Regnery. Washington, D.C.: Regnery Publishing, $7^{\mathrm{a}}$ ed. rev., 1986. p. 285. 
oligarquia daqueles que parecem estar por aí meramente de passagem ${ }^{30}$.

A ideia de democracia dos mortos se assemelha ao que Burke denominou "contrato primitivo da sociedade eterna", considerado como o elo "que liga as naturezas mais baixas às mais elevadas, liga o mundo visível com o invisível, conforme a inviolável lei que mantém todas as naturezas morais e físicas, cada uma em um lugar determinado"31. Tanto o contrato primitivo da sociedade eterna burkeano quanto a democracia dos mortos chestertoniana são entendidos na perspectiva kirkeana como o elemento da tradição, no sentido elioteano ${ }^{32}$, que relaciona o transcendente com o imanente $\mathrm{e}$ que conecta as diferentes gerações, vistos por Russell Kirk como uma aliança que une todos os seres humanos em um pacto imortal "feito entre Deus e a humanidade, e entre as gerações que desapareceram da Terra, a geração que ora vive, $e$ as gerações ainda por chegar"33. Tal perspectiva é a mesma defendida por Tolkien no ensaio "Sobre História de Fadas", no qual afirma que "as histórias de fadas podem ser melhores Mestres de Artes do que o indivíduo acadêmico"34.

A concepção de democracia dos mortos é um dos elementos centrais da noção chertertoniana de "ética da terra dos elfos", também denominada "ética dos contos de fadas" ${ }^{35}$ ou "ética do reino encantado" 36 , cuja ideia prin-

${ }^{30}$ CHESTERTON, G. K. Ortodoxia. Apr., notas e anexo Ives Gandra da Silva Martins Filho, trad. Cláudia Albuquerque Tavares. São Paulo: Editora LTr, 2001. p. 69.

${ }^{31}$ BURKE. Reflexões sobre a Revolução em França. p. 116.

${ }^{32}$ KIRK. A Era de T. S. Eliot. p. 199-202, 373-74.

${ }^{33}$ Idem. A Arte Normativa e os Vícios Modernos. p. 1006.

34 TOLKIEN. Sobre Histórias de Fadas. p. 71.

${ }^{35}$ CHESTERTON, G. K. A Ética dos Contos de Fadas. Trad. Márcia Xavier de Brito. The Chesterton Review: Edição Especial em Português, v. 1, n. 1, p. 16-19, 2009.

${ }^{36}$ Idem. A Ética do Reino Encantado. Trad. Márcia Xavier de Brito. The Chesterton Review: Edição Especial em Português, v. 1, n. 1, p. 6-9, 2009. cipal é a de que os mitos, fábulas, alegorias e parábolas, mais que os argumentos racionais, são os meios mais efetivos para se transmitir às gerações vindouras as normas apreendidas pelo senso comum e pelos costumes tradicionais, que para Kirk "são expressões práticas do que a humanidade aprendeu na escola das quedas e tropeços" ${ }^{\prime 37}$, visto que "mitos, fábulas e alegorias são antigos caminhos para a verdade" ${ }^{\prime 38}$.

As escolhas pessoais não são postas diante de uma liberdade absoluta, visto que para Chesterton, assim como nos contos de fada, "a felicidade é radiante, mas frágil", dependendo "de não fazer alguma coisa que em qualquer momento poderia ser feita e muitas vezes, sem que fosse óbvia a razão pela qual não se devia fazê- la"39. Esse é o "princípio da felicidade condicional", que advoga ser a alegria humana dependente da observância de um conjunto mínimo de algumas normas morais, necessárias e razoáveis, que, caso sejam desprezadas, acabam por quebrar o encanto e a harmonia da vida. Tal normatividade moral não deve ser imposta externamente por algum poder estatal ou privado, mas deve ser entronizada livremente na consciência dos indivíduos por intermédio da imaginação moral.

O processo criativo da imaginação moral é contraposto por Kirk às formas anárquicas e corrompidas de imaginário, que se tornaram mais comuns na modernidade ${ }^{40}$. Sustentada teoricamente em visões ideológicas sobre o homem e a sociedade, as duas formas corrompidas de imaginação, dominantes no cenário cultural de nossa época, colaboram com o processo de "desagregação normativa" da civilização ocidental, pois tanto a boa quanto a má literatura "exercem influência poderosa sobre o caráter privado e sobre a organiza-

\footnotetext{
${ }^{37}$ KIRK. A Arte Normativa e os Vícios Modernos. p. 1014.

${ }^{38}$ Idem. Tolkien e a Verdade da Fantasia. p. 783.

${ }^{39}$ CHESTERTON. Ortodoxia. p. 80.

${ }^{40}$ KIRK. A Imaginação Moral. p. 104-06; Idem, A Era de
}

T. S. Eliot. p. 140-41. 
ção política da sociedade"4t, visto que "à medida que a literatura se afunda na perversidade, da mesma forma a civilização moderna se desfaz em ruínas" 42 .

A primeira forma de imaginário degenerado é aquela nutrida pelos ideais românticos rousseanianos da "imaginação idílica", um tipo anárquico que "na busca de emancipação dos constrangimentos convencionais, se torna fantástica e sem restrições, primitivista e utópica, numa total rejeiçãa e revolta contra velhos dogmas, hábitos e costumes"43. O termo "imaginação idílica" foi retirado do título do segundo capítulo do livro Democracy and Leadership [Democracia e Liderança] de Irving Babbitt, publicado originalmente em 1924, no qual são analisados os vários problemas inerentes ao pensamento político e cultural de Jean-Jacques Rousseau (1712-1778) $)^{44}$. O romantismo apresentado pelo humanitarismo sentimental de Rousseau, tal como descrito por Kirk, é um "impulso pérfido para romper com o que Burke havia chamado de 'o contrato da sociedade eterna' $e$ para substituir a obrigação moral pelo culto de um egoísmo temerário" ${ }^{45}$. Nessa perspectiva, afirma Babbitt que sua preocupação "é com a relação desse tipo de imaginação com o moderno idealismo político", pois "o agitador apela principalmente a ela quando instiga a multidão com suas imagens da felicidade que deverá sobrevir depois da destruição da ordem social vigente"46. Um discípulo de Kirk, o professor Vigen Guroian, apresenta uma síntese dos riscos desse tipo de imaginário utópico:

O eu que é apanhado pela imaginação idílica é escapista, não no sentido que foge do meio físico que o cerca tanto quanto se esquiva das responsabilidades civis, sociais e morais. Isso é acompanhado e reforçado pela rejeição e revolta contra velhos dog-

\footnotetext{
${ }^{41}$ Idem. A Arte Normativa e os Vícios Modernos. p. 993.

${ }^{42}$ Idem. A Imaginação Moral. p. 106.

${ }^{43}$ CATHARINO. Russell Kirk (1918-1994). p. 292.

${ }^{44}$ BABBITT. Democracia e Liderança. p. 91-117.

${ }^{45}$ KIRK. A Era de T. S. Eliot. p. 165.

${ }^{46}$ BABBITT. Democracia e Liderança. p. 101.
}

mas, hábitos e costumes. A imaginação idílica está em busca de emancipação dos constrangimentos convencionais. Em nosso meio democrático e individualista, as pessoas justificam essa "libertação" em nome de uma autosatisfação e da autorealização, pois acreditam que as normas e estruturas existentes inibem ou obstruem. Com muita freqüência, há um desvio para idéias hedonistas, para uma sensualidade flagrante, e para as explorações da "carne". Esses são caminhos que prometem felicidade, porém, quase sempre não a encontram, e levam, ao contrário, ao enfado e ao tédio, ou pior, à dissipação física ou espiritual. Isso está bastante documentado em estudos clínicos e pela grande literatura moderna $[\ldots]^{47}$.

Dentre as inúmeras obras literárias modernas que retratam esse imaginário idíli$\mathrm{co}$, se destaca a maioria dos escritos no período do romantismo, que foram influenciados pelo espírito rousseauniano do naturalismo presente no ideal pastoral; bem como quase todas as obras de ficção científica, definidas por Tolkien como a "mais escapista de todas as formas literárias", cujos autores, na tentativa de agir como profetas de uma Nova Era, são reflexo da enfermidade moderna, nutrindo um "desejo de escapar, não de fato da vida, mas sim de nosso tempo presente e da miséria que nós mesmos fizemos" ${ }^{\prime 48}$.

"O que é notável sobre esse período que começa no século XVIII", ressalta Babbitt, "é a extensão com que não só os menos graduados como também os líderes foram seduzidos pelo chamariz da imaginação idílica". A promessa de criação do paraíso terreno está, necessariamente, fadada ao fracasso, por conta das próprias limitações da imperfectibilidade inerente à natureza humana, fazendo, assim, que o projeto útopico de construção de um "mundo melhor", pautado na "busca idílica pela paz, pelo prazer ou pela indiferença, e a remoção de qualquer responsabilidade social", não seja possível e te-

47 GUROIAN. A Imaginação Moral e os Contos de Fadas. p. 193.

48 TOLKIEN. Sobre Histórias de Fadas. p. 72-73. 
nha como único resultado "causar enfado"49. A imaginação idílica, de acordo com Kirk, "termina em desilusão e tédio", conduzindo, assim, ao "tipo de imaginação que se deleita no perverso e no sub-humano"50.

Tal imaginário decaído é a chamada "imaginação diabólica", a forma corrompida que se caracteriza "pela perda do conceito de pecado e pela concepção de natureza humana infinitamente maleável e mutável"; é a pervertida moralidade pluralista e mentalidade relativista do multiculturalismo que entendem "as normas morais como valores relativos às preferências individuais subjetivas ou à transitoriedade dos diferentes contextos culturais, defendendo a abolição de qualquer norma objetiva"51. O termo "imaginação diabólica" foi cunhado pelo próprio Russell Kirk para definir o tipo de imaginação descrita no livro After Strange Gods, de T. S. Eliot, na qual o autor afirma:

Nesta altura, arrisco generalizar e sugerir que com o desaparecimento da ideia de pecado original, com o desaparecimento da ideia de intensa luta moral, os seres humanos que nos são apresentados hoje, tanto em poesia quanto em prosa ficcional, e de forma mais evidente entre os escritores sérios do que no submundo das letras, tendem a ser cada vez menos reais. É, de fato, em momentos de batalhas espirituais e morais confiantes em sanções espirituais, e não naqueles "minutos desconcertantes" em que somos todos muito parecidos, que homens e mulheres chegam mais perto de se tornarem reais. Se acabarmos com esta luta, e sustentarmos que pela tolerância, benevolência, pela não-ofensividade, por uma redistribuição ou aumento do poder de compra, combinados com a devoção à arte por parte da elite, o mundo será tão bom quanto gostaríamos que fosse, então devemos esperar que os seres humanos tornem-se cada vez mais etéreos ${ }^{52}$.

${ }^{49}$ GUROIAN. A Imaginação Moral e os Contos de Fadas. p. 196.

${ }^{50}$ KIRK. A Imaginação Moral. p. 105.

${ }^{51}$ CATHARINO. A vida e a imaginação de Russell Kirk. p. 98.

${ }^{52}$ ELIOT, T. S. After Strange Gods: A Primer of Modern Heresy. Londres: Faber and Faber, 1934. p. 42.
"Essa imaginação diabólica predomina na maior parte da ficção popular de nossos dias; $e$, também, na televisão e nos cinemas", tal como ressalta Kirk, e "se mostra sem nenhum pudor"53. A imaginação diabólica, num certo sentido, existe de forma latente em todos os indivíduos, sendo "a imagem do demoníaco impressa pelo pecado original na alma humana"54.

Tanto a imaginação diabólica quanto a imaginação idílica não podem ser combatidas pela imposição de forças externas, como, por exemplo, um órgão governamental de censura ou alguma forma de inquisição eclesiástica. O único meio efetivo de represar o fluxo destruidor das formas corrompidas de imaginação é por intermédio das barreiras normativas criadas internamente no caráter individual pela imaginação moral. Desde a mais tenra idade a pessoa precisa ser exposta às mais diversas obras literárias que contenham elementos virtuosos. Dentre tais obras se destacam os contos de fadas de Charles Perrault (1628-1703), dos irmãos Jacob Grimm (17851863) e Wilhelm Grimm (1786-1859), de Hans Christian Andersen (1805-1875) e de Andrew Lang (1844-1912); as fábulas de Esopo (620560 a.C.) e de Jean de La Fontaine (1621-1695); as narrativas das mitologia greco-romana e da mitologia nórdica; os relatos bíblicos e as vidas dos santos; as lendas do Ciclo Arturiano e do Livro das Mil e Uma Noites; e os contos folclóricos de diferentes tradições culturais, tais como as narrativas populares brasileiras copiladas por João Simões Lopes Neto (18651916) e Luís da Câmara Cascudo (1898-1986); bem como, as estórias infanto-juvenis de George MacDonald (1824-1905), Carlo Collodi (1826-1890), Lewis Carroll (1832-1898), Frances Hodgson Burnett (1849-1924), Robert Louis Stevenson (1850-1894), Howard Pyle (18531911), Oscar Wilde (1854-1900), L. Frank Baum (1856-1919), Kenneth Grahame (1859-1932), J. M. Barrie (1860-1937), Rudyard Kipling (18651932), Beatrix Potter (1866-1943), Felix Salten

\footnotetext{
${ }^{53}$ KIRK. A Imaginação Moral. p. 105.

54 GUROIAN. A Imaginação Moral e os Contos de Fadas. p. 193.
} 
(1869-1945), A. A. Milne (1882-1956), Monteiro Lobato (1882-1948) e J. K. Rowling, dentre tantos outros que se dedicaram ao gênero literário. $\mathrm{O}$ jovem exposto à imaginação moral estará capacidado a reconhecer as verdades transcendentes da natureza humana até mesmo nas obras permeadas pela imaginação idílica ou pela imaginação diabólica, possibilitando compreender a diferença entre o que é humano e o que desumaniza a pessoa. A imaginação moral, no século $\mathrm{XX}$, foi promovida, principalmente, pelas obras de fantasia mitopoética de C. S. Lewis e de J. R. R. Tolkien.

\section{II - Os Fundamentos da Fantasia Mitopó́tica Tolkieniana}

No auge dos tumultos universitários que marcaram a chamada geração do "Maio de 68", Russell Kirk ressaltou a importância da imaginação moral veiculada em $O$ Senhor dos Anéis, em um artigo publicado em junho de 1968, num jornal de grande circulação, ao afirmar que mesmo sendo ambientada "fora do tempo e do espaço", "numa época que nunca existiu historicamente", a fantasia de J. R. R. Tolkien "é mais relevante para a presente condição humana do que qualquer discurso de políticos em campanha"55. A relevância moral e política dos escritos tolkienianos ressaltada por Kirk deve-se ao fato da narrativa de $O$ Senhor dos Anéis ser permeada pelos princípios permanentes da Lei Natural, o que a torna um antídoto para os males da modernidade ${ }^{56}$. Tanto os livros quanto as versões cinematográficas de Peter Jackson apresentam a reverência de

\footnotetext{
${ }^{55}$ KIRK. Tolkien e a Verdade da Fantasia. p. 783.

56 Para uma análise geral da narrativa da obra, enfatizando os princípios defendidos pelo pensamento tolkieniano, ver: RUTLEDGE, Fleming. The Battle for Middle-Earth: Tolkien's Divine Design in The Lord of the Rings. Grand Rapids: Wm. B. Eerdmans Publishing, 2004. Para uma síntese da estória de Tolkien em língua portuguesa, ver: MARTINS FILHO, Ives Gandra. Sinopse de O Senhor dos Anéis. In: O Mundo do Senhor dos Anéis: Vida e obra de J. R. R. Tolkien. São Paulo: Martins Fontes, 2ª ed., 2006. p. 109-50.
}

Tolkien pelo mundo da natureza, pelo mundo da tradição e pelo mundo espiritual da Providência ${ }^{57}$. Em seus aspectos negativos, a modernidade pode ser entendida como a rebelião humana contra a natureza, a tradição e a religião, ao passo que a narrativa de $O$ Senhor dos Anéis, possibilita evocar na imaginação dos modernos uma nostalgia por esses três mundos, pois "a Terra Média, afinal, é uma representação das desordens de nosso tempo presente, e os desígnios de Sauron são as tendências desumanizantes de nossa época"158. Contudo, tal perspectiva restauradora não é uma fuga utópica da realidade de nossa era, mas um reavivamento terapêutico dessa tripla reverência na vida do homem moderno, "tentando preservar a natureza, respeitando as tradições valiosas de nossa cultura (chame, se quiser, de 'conservadorismo com discernimento') e, finalmente, aprofundando a vida espiritual" ${ }^{\prime \prime}$.

O entendimento da imaginação moral tolkieniana, em grande parte, está subordinado ao conhecimento da biografia de J. R. R. Tolkien. Não cabe aqui uma descrição detalhada da vida desse literato ${ }^{60}$, no entanto, dois aspectos biográficos são fundamentais para o entendimento de $O$ Senhor dos Anéis: o espiritual e o profissional. Ao longo de toda a vida, Tolkien foi um católico extremamente devoto, dotado de uma fé plenamente vivenciada nos sacramentos, o que deixou marcas profundas, mesmo que inconscientes, em sua produção literária, a ponto de ser impossível pensar as suas obras "como algo apartado de sua igreja é,

57 CALDECOTT, Stratford. A Graça dos Vala: O Filme O Senhor dos Anéis. Trad. Márcio Nicodemos. COMMUNIO: Revista Internacional de Teologia e Cultura, v. 28, n. 1, p. 201-12. Jan.-Mar. 2009, p. 208-10.

${ }^{58}$ KIRK. Tolkien e a Verdade da Fantasia. p. 784.

${ }^{59}$ CALDECOTT. A Graça dos Vala: O Filme O Senhor dos Anéis. p. 210.

60 Dentre as inúmeras obras dedicadas a essa tarefa ganha destaque a seguinte biografia autorizada: CARPENTER, Humphrey. J. R. R. Tolkien: A Biography. Boston: Houghton Mifflin Company, 2000. Para uma breve biografia em língua portuguesa, ver: MARTINS FILHO, Ives Gandra. Vida de J. R. R. Tolkien. In: O Mundo do Senhor dos Anéis. p. 37-48. 
portanto, tão absurdo quanto pensá-las como algo separado de sua vida"61. A carreira profissional, dedicada ao estudo e ao magistério de Filologia, é outro fator fundamental, visto que o interesse do autor pela origem das palavras e pela pesquisa de línguas antigas como o grego, o latim, o anglo-saxão, o gaélico, o galês, o islândes e finlandês, levaram-no à criação de novos idiomas, como o quenya (alto-élfico) e o sindarin (élfico-cinzento), que estão na origem da composição de $O$ Senhor dos Anéis, entendido por Tolkien como "um ensaio de estética linguística", pois tais narrativas "foram feitas para proporcionar um mundo para as línguas que criara $^{\prime \prime 62}$. Sobre as origens linguísticas de $O$

61 EDWARDS, Owen Dudley. Gollum, Frodo e o Romance Católico. Trad. Márcia Xavier de Brito. COMMUNIO: Revista Internacional de Teologia e Cultura, v. 28, n. 1, p. 185-200. Jan.-Mar. 2009, p. 187. Além da já citada biografia autorizada de Humphrey Carpenter e do estudo J. R. R. Tolkien's Sanctifying Myth: Understanding Middle-earth do historiador Bradley J. Birzer, o catolicismo do criador da saga $O$ Senhor dos Anéis é destacado em inúmeros trabalhos, dentre os quais elencamos: PEARCE, Joseph. Tolkien, Man and Myth: A Literary Life. San Francisco: Ignatius Press, 1998; CALDECOTT, Stratford. The Power of the Ring: The Spiritual Vision behind The Lord of the Rings and The Hobbit. New York: Crossroad Book, $2^{\text {nd }}$ Rev. Ed., 2012; KREEFT, Peter. The Philosophy of Tolkien: The Worldview behind The Lord of the Rings. San Francisco: Ignatius Press, 2005. Ver, também, os inúmeros relatos do próprio Tolkien sobre a fé católica e os sacramentos em algumas de suas cartas, publicadas em língua portuguesa na seguinte edição brasileira: TOLKIEN, J. R. R. As Cartas de J. R. R. Tolkien. Org. Humphrey Carpenter, com a assistência de Christopher Tolkien; Trad. Gabriel Blum Oliva. Curitiba: Arte e Letra Editora. 2006. Esp. p. 13, 56-57, 69, 86, 114, 167, 245, 275, 307, 321-24, 335-36, 379$80,427$.

${ }^{62}$ MARTINS FILHO, Ives Gandra da Silva. Cristianismo no mundo do Senhor dos Anéis: A perspectiva cristã na obra de J. R. R. Tolkien. COMMUNIO: Revista Internacional de Teologia e Cultura, v. 26, n. 3, p. 613-23. Set.-Dez. 2007. p. 617. Numa carta, publicada parcialmente no New York Times Book Review em 5 de junho de 1955, Tolkien afirmou: "Sou um filólogo e todo o meu trabalho é filológico. Evito passatempos porque sou uma pessoa muito séria e não consigo distinguir entre entre divertimento particular e obrigação. Sou afável, mas insociável. Trabalho apenas para divertimento particular, uma vez que acho minhas obrigações particularmente
Senhor dos Anéis, bem como a relação da obra tanto com The Hobbit [O Hobbit] ${ }^{63}$, publicado originalmente em inglês em 1937 e reeditado numa versão revista pelo autor em 1951], quanto com The Silmarillion [O Silmarillion] ${ }^{64}$ e com os Unfinished Tales of Númenor and Middle-earth [Contos Inacabados de Númenor e da Terra Média] ${ }^{65}$, lançados postumamente em 1977 e em 1980, escreveu Tolkien no prefácio de $A$ Sociedade do Anel, primeiro volume da obra:

Esta história cresceu conforme foi sendo contada, até se tornar uma história da Grande Guerra do Anel, incluindo muitas passagens da história ainda mais antiga que a

divertidas" (TOLKIEN. As Cartas de J. R. R. Tolkien. p. 209). Para uma análise mais detalhada sobre os fundamentos filológicos e as bases literárias da ficção tolkieniana, ver: SHIPPEY, Tom. The Road to Middle-Earth: How J. R. R. Tolkien Created a New Mythology. New York: Houghton Mifflin Company, 2003. Ver, também: SHIPPEY, Tom. Creation from Philology in The Lord of the Rings. In: SALU, Mary \& FARRELL, Robert T. (Ed.). J. R. R. Tolkien, Scholar and Storyteller: Essays in Memoriam. Ithaca: Cornell University Press, 1979. p. 286-316. Sete ensaios acadêmicos de Tolkien foram compilados no seguinte volume: TOLKIEN, J. R. R. The Monster and the Critics and Other Essays. Ed. Christopher Tolkien. London: Harper Collins Publishers, 2006.

${ }_{63}$ TOLKIEN. J. R. R. O Hobbit. Trad. Lenita Maria Rímoli Esteves e Almiro Pisetta. São Paulo: Martins Fontes, $2^{\underline{a}}$ ed., 1998. Para uma análise sintética da obra, ver: SHIPPEY, Tom. The Hobbit: Re-Inventing Middle-Earth. In: J. R. R. Tolkien: Author of the Century. p. 1-49. Uma síntese da estória em língua portuguesa foi publicada em: MARTINS FILHO, Ives Gandra. Sinopse de O Hobbit. In: O Mundo do Senhor dos Anéis. p. 101-08.

${ }^{64}$ TOLKIEN. J. R. R. O Silmarillion. Org. Christopher Tolkien; Trad. Waldéa Barcellos. São Paulo: Martins Fontes, $3^{\mathrm{a}}$ ed., 2007. Ver, também: SHIPPEY, Tom. The Silmarillion: The Work of His Heart. J. R. R. Tolkien: Author of the Century. p. 226-63; MARTINS FILHO, Ives Gandra. Sinopse de O Silmarillion. In: O Mundo do Senhor dos Anéis. p. 59-78.

${ }^{65}$ TOLKIEN. J. R. R. Contos Inacabados: De Númenor e da Terra-média. Org. Christopher Tolkien; Trad. Ronald Eduard Kyrmse. São Paulo: Martins Fontes, 2002. Ver, também: MARTINS FILHO, Ives Gandra. Sinopse de Contos Inacabados de Númenor e da Terra Média. In: O Mundo do Senhor dos Anéis. p. 79-100. 
precedeu. O conto foi iniciado logo depois que $O$ Hobbit foi escrito e antes de sua publicação, em 1937; mas não continuou nessa sequência, pois eu queria primeiro completar e colocar em ordem a mitologia e as lendas dos Dias Antigos, que já vinham tomando forma havia alguns anos. Quis fazer isso para a minha própria satisfação, e tinha alguma esperança que outras pessoas ficassem interessadas nesse trabalho, especialmente por ele ser fruto de uma inspiração primordialmente linguística, e por ter sido iniciado a fim de fornecer o pano de fundo "histórico" necessário para as línguas élficas ${ }^{66}$.

A criação do universo ficcional da Terra-Média se deu no período em que Tolkien serviu como soldado britânico nas trincheiras da Primeira Guerra Mundial ${ }^{67}$, sendo desenvolvido, gradativamente, ao longo de todo o resto de sua vida. Ainda no prefácio de $A$ Sociedade do Anel, Tolkien descreve a forma como desenvolveu o processo de criação de sua obra-prima:

A composição de O Senhor dos Anéis aconteceu em intervalos entre os anos de $1936 \mathrm{e}$ 1949, um período no qual eu tinha muitos deveres que não negligenciei, e muitos outros interesses como estudante e professor que frequentemente me absorviam. A demora, sem dúvida aumentou com o estouro da guerra em 1939 [...]. Apesar da escuridão dos cinco anos seguintes, descobri que a história não podia ser inteiramente abandonada, e continuei de maneira árdua, principalmente à noite [...]. Todavia, passaram-se mais de cinco anos até o conto chegar ao seu final atual [...]. Então, quando o "final" fora atingido, a história inteira precisava ser re-

${ }^{66}$ TOLKIEN. O Senhor dos Anéis: A Sociedade do Anel. p. xi. Deste ponto em diante, do presente artigo, sempre que citarmos passagens de O Senhor dos Anéis, utilizaremos apenas os subtítulos do volume utilizado, de acordo com as notas de rodapé 1,2 e 3 .

${ }^{67}$ Sobre as relações entre a biografia de Tolkien durante a Primeira Guerra Mundial e o processo de criação da Terra-Média, consultar a seguinte obra: GARTH, John. Tolkien and the Great War: The Thereshold of Middle-earth. Boston: Houghton Mifflin Company, 2003. visada e, na verdade, em grande parte reescrita $[\ldots]^{68}$.

O publico original de O Senhor dos Anéis, assim como de O Hobbitt, eram os próprios filhos de J. R. R. Tolkien. Parte significativa dos manuscritos de $O$ Senhor dos Anéis foi enviada pelo autor para seu terceiro filho, Christopher Tolkien, que durante a Segunda Guerra Mundial serviu à Royal Air Force (R.A.F.) na África do Sul ${ }^{69}$ e que, desde a morte do pai, tornou-se o responsável pela publicação de uma série de textos inéditos de J. R. R. Tolkien. Antes da publicação, o texto, também, foi lido e comentado pelos amigos e literatos C. S. Lewis e Charles Williams (18861945), membros, junto com Tolkien, de um grupo literário informal denominado Inklings [suspeitas/ pressentimentos/ ideias vagas], que aprovaram entusiaticamente a obra ${ }^{70}$.

${ }^{68}$ TOLKIEN. A Sociedade do Anel. p. xi-xii.

${ }^{69}$ Além de mencionar tal fato no prefácio do livro $A$ Sociedade do Anel (p. xii), em inúmeras cartas de J. R. R. Tolkien para o filho Christopher Tolkien encontramos referências ao envio anexo de manuscritos da obra $O$ Senhor dos Anéis. Ver: TOLKIEN. As Cartas de J. R. R. Tolkien. Esp. p. 93, 103-07, 110.

${ }^{70}$ Em uma carta, datada de 31 de julho de 1947, para o editor Sir Stanley Unwin (1884-1968), escreveu Tolkien: "O público que até agora acompanhou O Anel, capítulo a capítulo, leu-o e clama por mais, é composto de uma gente singular de gostos literários similares, tais como C. S. Lewis, o finado Charles Williams e meu filho Christopher; eles provavelmente são uma minoria muito pequena e não correspondida" (TOLKIEN. As Cartas de J. R. R. Tolkien. p. 121). Nesta mesma carta o autor informa que parte significativa da obra, também, foi lida por outras pessoas, cujos nomes não são citados, mas, que, provavelmente, eram participantes do grupo literário informal dos Inklings, do qual além de J. R. R. Tolkien, C. S. Lewis, Charles Williams e Christopher Tolkien, faziam parte, também, o major aposentado do Exército Britânico e historiador W. H. Lewis (1895-1973), irmão mais velho de C. S. Lewis, o filósofo e poeta Owen Barfield (1898-1997), o professor de inglês Hugo Dyson (1896-1975), o poeta e cônego anglicano Adam Fox (1883-1977), e o romancista e biógrafo Roger Lancelyn Green (1918-1987), dentre outros. Para maiores informações sobre o grupo dos Inklings, ver: CARPENTER, Humphrey. The Inklings: C. S. Lewis, J. R. R. Tolkien, Charles Williams and 
O detalhado processo criativo tolkieniano pode ser explicado metaforicamente pelo conto Folha por Niggle, publicado originalmente na Dublin Review em 1947, em que Tolkien relata a tentativa de um pintor, vivendo numa sociedade onde não se valorizam as artes, de transpor a visão de uma árvore para a tela, pintando com o máximo de detalhes a beleza de cada uma das folhas, e sendo, no entanto, interrompido, freqüentemente, pelas contingências do cotidiano ${ }^{71}$. A leitura conjunta desse conto com o ensaio "Sobre Histórias de Fadas" de Tolkien ajuda a responder o porquê do autor, muitas vezes em detrimento da própria carreira acadêmica, ter passado mais de meio século criando o mundo imaginário da Terra Média.

O referido ensaio de J. R. R. Tolkien é a versão ampliada de uma palestra sobre o já citado escritor Andrew Lang, apresentada, em 8 de março de 1939, na Universidade de Saint Andrews, na Escócia. Tendo como fio condutor a série de contos compilados por Lang e outros textos da literatura universal, Tolkien se propõe a "falar de histórias de fadas, embora esteja consciente de que essa é uma aventura temerária"72. Ao longo do ensaio tenta responder a três perguntas fundamentais sobre o tema, a saber:

their friends. Boston: Houghton Mifflin Company, 1979; DURIEZ, Colin \& PORTER, David. The Inklings Handbook: The Lives, Thought and Writings of C. S. Lewis, J. R. R. Tolkien, Charles Williams, Owen Barfield, and Their Friends. Atlanta: Chalice Press, 2001. Em língua portuguesa, ver: DEVAUX, Michaël. Itinerarium imaginationis ad Deum: Viagem a Númenor na companhia dos Inklings. Trad. Maria Francisca Alves de Souza. COMMUNIO: Revista Internacional de Teologia e Cultura, v. 28, n. 1, p. 151-72. Jan.-Mar. 2009.

71 TOLKIEN, J. R. R. Folha por Niggle. In: Sobre Histórias de Fadas. p. 92-118. Para uma análise dos aspectos autobiográficos do conto, bem como da obra Smith of Wootton Major de 1967, ver: SHIPPEY, Tom. Shorter Works: Doubts, Fears, Authobiographies. In: J. R. R. Tolkien: Author of the Century. p. 264-304.

72 TOLKIEN. Sobre Histórias de Fadas. p. 9.
1ํ) "O que é uma história de fadas?"73;

$\left.2^{a}\right)$ "Quais são as origens das histórias de fadas?"74;

$3^{\text {a) }}$ "Quais são, se é que existem, os valores e as funções das histórias de fadas, hoje?"75.

A definição do que são (ou deveriam ser) as histórias de fadas independe de tratar ou não de fadas ou elfos. A principal característica, como ressalta Tolkien, deve ser estar relacionada, de alguma forma, ao Belo Reino [Faërie, Fairy], e tratar das aventuras dos homens nesse mundo encantado, independente da finalidade principal do texto ser sátira, aventura, moralidade ou fantasia. $\mathrm{O}$ elemento mágico é um ponto constante nessas histórias, entretanto a magia do Belo Reino não é um fim em si mesmo, estando relacionada à virtude de como tais poderes são utilizados. Na categoria de "história de fadas" não se deve incluir as fábulas de animais, as narrativas onde a tecnologia é um artifício para a entrada no Belo Reino ou os contos oníricos. Tolkien insiste que "é essencial à história de fadas genuína, diferentemente do uso dessa forma para fins menores ou aviltados, que ela seja apresentada como 'verdadeira', pois ao tratar de 'maravilhas', não se pode entender que a narrativa é uma ficção ou ilusão"

A questão da origem, dentre as três perguntas formuladas, é para Tolkien a de menor importância, pois foge à capacidade humana traçar a genealogia desses relatos, visto que " $a$ história dos contos de fadas provavelmente é mais complexa que a da raça humana e tão complexa quanto a da linguagem humana". Na produção da intrincada teia da história dos contos de fadas existem três fatores fundamentais:

$\left.1^{\circ}\right)$ A Invenção independente de relatos semelhantes, que é o fator "mais importante $e$ fundamental", mas, também, o mais misterioso;

$2^{\circ}$ ) A Difusão de um ou mais centros, em várias épocas, entendida como um "emprésti-

\footnotetext{
${ }^{73}$ Ibidem. p. 10.

${ }^{74}$ Ibidem. p. 23.

${ }^{75}$ Ibidem. p. 40.

${ }^{76}$ Ibidem. p. 20.
} 
mo no espaço", pelo qual uma narrativa sempre remete o problema da origem para um outro lugar;

$3^{\circ}$ ) A Herança de um antepassado comum para diferentes narrativas, definida como um "empréstimo no tempo", que aponta somente para "um inventor ancestral"77.

Tolkien acreditava ser um erro buscar as origens dos contos de fadas em alegorias de fenômenos naturais, em crenças religiosas ou em eventos históricos. Nesse sentido, a própria criação tolkieniana não deve ser interpretada como uma alegoria da fé do autor ou do contexto histórico em que viveu, pois como ressalta Tolkien no prefácio de $A$ Sociedade do Anel:

Quanto a qualquer significado oculto ou "mensagem", na intenção do autor estes não existem. O livro não é nem alegórico e nem se refere a fatos contemporâneos. [...] Outros arranjos [em O Senhor dos Anéis] poderiam ser criados de acordo com os gostos ou as visões daqueles que gostam de alegorias ou referências tópicas. Mas eu cordialmente desgosto de alegorias em todas as suas manifestações, e sempre foi assim desde que me tornei adulto e perspicaz o suficiente para detectar a sua presença. Gosto muito mais de histórias, verdadeiras ou inventadas, com uma aplicabilidade variada ao pensamento e à experiência dos leitores. Acho que muitos confundem "aplicabilidade" com "alegoria"; mas a primeira reside na liberdade do leitor, e a segunda na dominação proposital do autor. É claro que o autor não consegue ser afetado por sua própria experiência, mas os modos pelos quais os germes da história usam o solo da experiência são extremamente complexos, e as tentativas de definição do processo são, na melhor das hipóteses, suposições feitas a partir de evidências inadequadas e ambíguas ${ }^{78}$.

Tolkien escreveu, numa carta datada de 17 de novembro de 1957, sobre o problema da busca por símbolos ocultos ou da utiliza-

\footnotetext{
${ }^{77}$ Ibidem. p. 27.

${ }^{78}$ TOLKIEN. A Sociedade do Anel. p. xii-xiii.
}

ção de alegorias conscientes em $O$ Senhor dos Anéis:

Não há "simbolismo" ou alegoria consciente em minha história. Alegorias do tipo "cinco magos = cinco sentidos" são completamente estranhas ao meu modo de pensar. Havia cinco magos e esta é apenas uma parte única da história. Perguntar se os Orcs 'são' comunistas para mim é tão sensato quanto perguntar se os comunistas são Orcs.

Por não haver alegoria não quer dizer, é claro, que não há aplicabilidade. Sempre há. E visto que não tornei o conflito inequívoco [...], suponho que haja aplicabilidade em minha história aos tempos atuais. Mas devo dizer, caso perguntado, que a história não é realmente sobre Poder e Domínio: isso apenas mantém as rodas girando; ela é sobre a Morte e o desejo pela imortalidade. Que não mais é do que dizer que esta é uma história escrita por um Homem! ${ }^{79}$.

Em uma longuíssima carta, escrita, provavelmente, no final de 1951, na qual, de forma resumida, apresenta as linhas gerais do enredo de $O$ Silmarillion e de $O$ Senhor dos Anéis, Tolkien afirma:

Mitos e contos de fadas, como toda arte, devem refletir e conter elementos de verdade (ou erro) moral e religiosa, mas não explícitos, não na forma conhecida do mundo "real" primário. (Refiro-me, é claro, à nossa situação atual, não aos antigos dias pagãos, pré-cristãos. E não repetirei o que tentei dizer em meu ensaio ["Sobre Histórias de Fadas"]). [...]

Desagrada-me a Alegoria - a alegoria consciente e intencional; todavia, qualquer tentativa de explicar o propósito dos mitos e dos contos de fadas deve empregar uma linguagem alegórica. (E, é claro, quanto mais vida uma história tiver, mais facilmente ela será suscetível a interpretações alegóricas, ao passo que quanto melhor uma alegoria deliberada for feita, mais prontamente ela será aceita apenas como uma história) $)^{80}$.

\footnotetext{
${ }^{79}$ Idem. As Cartas de J. R. R. Tolkien. p. 250.

${ }^{80}$ Ibidem. p. 141-42.
} 
No ensaio "Sobre História de Fadas", defende que, "como relíquias de antigos costumes outrora praticados na vida diária", tais narrativas podem produzir, ainda em nossos dias, efeitos significativos ${ }^{81}$. Não devemos acreditar que tal gênero literário é destinado apenas às crianças, "na verdade, a associação entre crianças e histórias de fadas é um acidente de nossa história doméstica"; o mundo letrado moderno relegou o gênero ao berçário, do mesmo modo "como a mobilia velha ou fora de moda é relegada à sala de recreação, principalmente porque os adultos não as querem mais e não se importam se a usarem de forma inadequada"s2. Tolkien defende que os adultos, também, "devem ler histórias de fadas como um ramo natural da literatura", pois se beneficiarão com tais narrativas, que "se forem escritas com arte" terão como valor primordial a mesma beleza, também, fornecida por outros gêneros literários, além de oferecer, de modo peculiar, importantes elementos de "Fantasia, Recuperação, Escape e Consolo"83.

O maior risco dos modernos é perder o senso de humanidade em um mundo dominado pelo enfado, alimentado por formas artísticas intencionalmente ineptas, canhestras e disformes, além de obscuras e incessantemente violentas. Diante desse contexto cultural desolador, as histórias de fadas possibilitam a recuperação de um encantamento pela realidade via Fantasia. "A recuperação (que inclui o retorno e a renovação) é uma 're-tomada' - a retomada de uma visão clara", não para ver as coisas, apenas, como realmente são, mas para "ver as coisas como nós devemos (ou deveríamos) vê-las" ${ }^{\prime \prime 4}$. Tal recuperação permite um Escape, entendido como "o Escape do Prisioneiro", que não deve ser confundido com "a Fuga do Desertor", visto que a última é uma fuga escapista da realidade, pautada na repugnância, na raiva, na condenação e na revolta ${ }^{85}$. A noção

\footnotetext{
${ }^{81}$ Idem. Sobre Histórias de Fadas. p. 38.

${ }^{82}$ Ibidem. p. 41.

${ }^{83}$ Ibidem. p. 53.

${ }^{84}$ Ibidem. p. 65.

${ }^{85}$ Ibidem. p. 69.
}

de Escape proposta por Tolkien é uma libertação, mesmo que apenas na Fantasia, tanto do mal-estar gerado pelas modernas sociedades industriais quanto das "antigas limitações das quais as histórias de fadas oferecem uma espécie de escape, e velhas ambições e desejos (que tocam as próprias raizes da fantasia) aos quais oferecem um tipo de satisfação e consolo"s6. Dentre tais anseios, "existe o desejo mais antigos e profundo, o Grande Escape: o Escape da Morte" ${ }^{187}$, cujas histórias de fadas, muitas vezes, ensinam o fardo que é uma vida serial prolongada no mundo material, apontando a benção de uma imortalidade transcendende, encontrada apenas na morte, o grande tema da existência humana. Contudo, o mais importante aspecto de satisfação oferecido pelas histórias de fadas é "o Consolo do Final Feliz", expresso na noção tolkieniana de "Eucatástrofe", uma "virada" jubilosa na narrativa, que costuma ocorrer no momento de maior desespero, como uma ação inesperada da Providência, "dando um vislumbre fugaz da Alegria"88. Essa forma de Alegria foi escolhida por Tolkien "como sinal da verdadeira história de fadas" ${ }^{189}$. Nesse sentido, a Alegria oferecida pela Fantasia é um reflexo menor da alegria cristã, a Glória, que é "da mesma espécie, mas preminente (infinitamente, se não fosse finita nossa capacidade) elevada e jubilosa"90.

A Fantasia "não é uma forma inferior de Arte", mas uma forma superior, representando o tipo de imaginação "mais potente", por ser a "mais próxima da pura" criação artística", que "aspira à destreza élfica, o Encantamento, e quando bem-sucedida aproxima-se mais dele do que todas as formas da arte humana"92. Tolkien afirma que:

A Fantasia é uma atividade humana natural. Certamente ela não destrói, muito me-

\footnotetext{
${ }^{86}$ Ibidem. p. 74.

${ }^{87}$ Ibidem. p. 76.

${ }^{88}$ Ibidem. p. 76-77.

${ }^{89}$ Ibidem. p. 78.

${ }^{90}$ Ibidem. p. 81.

${ }^{91}$ Ibidem. p. 55.

${ }^{92}$ Ibidem. p. 61.
} 
nos insulta, a Razão; e não abranda o apetite pela verdade científica nem obscurece a percepção dela. Ao contrário. Quanto mais aguçada e clara for a razão, melhor fantasia produzirá. Se os homens estivessem num estado em que não quisessem conhecer ou não pudessem perceber a verdade (fatos ou evidências), então a Fantasia definharia até que eles se curassem. Se chegarem a atingir esse estado (o que não parece ser impossível), a Fantasia perecerá e se transformará em Ilusão Mórbida.

A Fantasia criativa está fundamentada no firme reconhecimento de que as coisas são assim no mundo [...], no reconhecimento do fato, mas não na escravidão perante ele. [...] Se as pessoas realmente não conseguissem distinguir entre sapos e homens, não teriam surgido histórias de fadas sobre reis sapos ${ }^{93}$.

Tal fundamentação realista acerca dos aspectos ontológicos e gnosiológicos da Fantasia é a base teórica do universo ficcional de O Senhor dos Anéis. O ponto fundamental do gênero literário denominado Fantasia Mitopoética é a capacidade do homem se tornar subcriador. Tal característica definidora desse gênero literário é explicada por Tolkien do seguinte modo:

Provavelmente todo escritor que faz um mundo secundário, uma fantasia, todo subcriador, deseja em certa medida ser um criador de verdade, ou espera estar se baseando na realidade: espera que a qualidade peculiar desse mundo secundário (senão todos os detalhes) seja derivada da Realidade, ou flua para ela. Se conseguir de fato uma qualidade que possa ser descrita honestamente pela definição de dicionário - "consistência interna da realidade" -, é difícil conceber como isso pode acontecer se a obra não tiver algumas características da realidade. A qualidade peculiar da "alegria" na Fantasia bem-sucedida pode, portanto, ser explicada como um repentino vislumbre da realidade ou verdade subjacente. Não é apenas um "consolo" para o pesar do mundo, mas uma satisfação, e uma resposta à pergunta: "É verdade?" A

\footnotetext{
${ }^{93}$ Ibidem. p. 62-63.
}

resposta a essa pergunta que dei inicialmente foi (muito corretamente): "Se você construiu bem seu pequeno mundo, sim, é verdade nesse mundo". Isso basta ao artista (ou à parte artística do artista). Mas na "eucatástrofe" enxergamos numa breve visão que a resposta pode ser maior - pode ser um lampejo longínquo ou eco do evangelium no mundo real. [...] É um assunto sério e perigoso. É presunção minha tocar em tal tema, mas se por algum tipo de graça o que digo tiver alguma validade sob algum ponto de vista, é claro que é apenas uma faceta de uma verdade incalculavelmente rica: finita somente porque é finita a capacidade do Homem para quem isso foi feito. [...] Deus redimiu as corruptas criaturas-criadoras, os homens, de maneira adequada a esse aspecto de sua estranha natureza, e também a outros. Os Evangelhos contêm uma história de fadas, ou uma narrativa maior que engloba toda a essência delas. Contêm muitas maravilhas - peculiarmente artísticas, belas e emocionantes: "míticas" no seu significado perfeito e encerrado em si mesmo - e entre as maravilhas está a maior e mais completa eucatástrofe concebível. Mas essa narrativa entrou para a História e o mundo primário. O desejo e a aspiração da subcriação foram elevados ao cumprimento da Criação. O Nascimento de Cristo é a eucatástrofe da história do Homem. A Ressurreição é a eucatástrofe da história da Encarnação. Essa história começa e termina em alegria. Ele tem preeminentemente a "consciência interna da realidade". Não há conto já contado que os homens mais queiram descobrir que é verdadeiro, e não há nenhum que tantos homens céticos tenham aceitado como verdadeiro por seus próprios méritos. Porque sua Arte tem o tom supremamente convincente da Arte Primária, isto é, da Criação. Rejeitá-lo leva à tristeza ou à ira.

[...] Mas essa história é suprema, everdadeira. A Arte foi verificada. Deus é o Senhor, dos anjos e dos homens - e dos elfos. A Lenda e a História encontraram-se e fundiram-se.

Mas no reino de Deus a presença do maior não deprecia o pequeno. O Homem redimido ainda é homem. A história e a fanta- 
sia ainda prosseguem, e devem prosseguir. O Evangelium não ab-rogou as lendas; ele as consagrou, em especial o "final feliz"94.

Há um aspecto intrínseco da antropologia judaico-cristã em todas as obras de Fantasia Mitopoética, mesmo as desprovidas de qualquer sacramentalidade, pois, nas palavras de Tolkien, "fazemos em nossa medida e em nosso modo derivativo, porque somos feitos, e não somente feitos, mas feitos à imagem e semelhança de um Criador"95. Esta "Perspectiva Criacionista" é refletida no universo ficcional da Terra Média, no qual o mundo é fruto da obra de uma divindade única chamada Eru ("O Único") ou Ilúvatar ("Pai de Todos"), que criou os Ainur ("Sagrados"), os seres de natureza angelical, que são puramente espirituais. Os Ainur que assumiram forma material são os Valar ("Poderes do Mundo"), de hierarquia superior, e os Maiar ("excelentes" ou "admiráveis"), de hierarquia inferior; ambos enviados no início dos tempos para criar, guardar e governar Eä (o mundo terreno). Saruman (o branco), Gandalf (o cinzento), Ragadast (o castanho), e Alatar e Pallando (os azuis) são os cinco Istari, que vieram à Terra Média sob a forma de magos, sendo na verdade Maiar enviados pelos Valar para ajudar na luta contra Sauron. O deus único desse universo ficcional, também, foi o responsável direto pela criação dos chamados "Filhos de Ilúvatar" - os Elfos ou Quendi ("os Primogênitos") e os Homens ou Atani ("os Sucessores") -, além de ser, diretamente ou indiretamente (pelas obras dos Ainur e dos Valar), o criador de toda a realidade material, incluindo os "Filhos de Aulë" (os Anões ou Ananos, também, chamados de Khazad, Hadhodrim, Casari, Naugrim ou Nogothrim), os Hobbits (os Pequenos, também, chamados Periannath pelos elfos), e os Ents e Huorns (seres arvorescos), além dos animais falantes e pensantes, como os dragões, as águias e tantos outros que povoam as narrativas tolkienianas ${ }^{96}$.

\footnotetext{
${ }^{94}$ Ibidem. p. 79-81.

${ }^{95}$ Ibidem. p. 63.

${ }^{96}$ A mitologia criacionista tolkieniana é apresentada numa narrativa mais sistemática em $O$ Silmarillion.
}

A "Perspectiva Criacionista" possui uma relação direta com os temas da Queda, da Morte e do Poder (representado simbolicamente pela Magia ou pela Máquina), que dão vida à "Perspectiva Ética" da narratologia tolkieniana, que "se mostra no ressaltar as grandezas e misérias da alma, conforme as virtudes e os vícios dos personagens", todavia, ao tomar a liberdade moral como pré-condição da ação das personagens, encontramos um grau de imprevisibilidade no desenvolver da narrativa de Tolkien, pois, "ninguém está a salvo de se corromper, como também ninguém está irremediavelmente perdido"97.

Tanto a "Perspectiva Criacionista" quanto a "Perspectiva Ética" constituem a essência da narrativa de O Senhor dos Anéis, e criam a tensão entre Providência - caracterizada pelas diversas "viradas" eucatastróficas - , e Liberdade - manifesta na adesão ou rejeição voluntária às virtudes. Nesse contexto de aventuras de Homens, Elfos, Ananos e Hobbits, a coragem figura entre uma das mais importantes virtudes. No orgulho de Melkor ("Aquele que se ergue em poder"), também chamado de Morgoth ("o Sinistro Inimigo do Mundo"), um Vala cujo intento era desfazer toda a obra Ilúvatar, encontra-se origem da Queda no universo fantástico tolkieniano. A dissonância de Melkor com a Grande Música criadora de Ilúvatar foi o fator que levou à perversão de alguns dos Maiar, dentre eles Mairon ("o Admirável"), o servidor de Melkor, que após ser corrompido passou a ser conhecido como Sauron ("o Abominado"); ao passo que os Orcs são elfos pervertidos, criaturas decaídas, desprovidas da beleza e da sabedoria intrínsecas à natureza élfica. Por outro lado, na misericórdia de Bilbo, na humildade de Frodo e na fidelidade de Sam, bem como na amizade, na coragem e no sacrifício dos demais heróis da saga, encontra-se a

Relatos complementares estão dispersos ao longo dos Contos Inacabados, de O Hobbit e de O Senhor dos Anéis.

97 MARTINS FILHO. Cristianismo no mundo do Senhor dos Anéis: A perspectiva cristã na obra de J. R. R. Tolkien. p. 617. 
salvação da Terra Média, iniciada na aceitação da tarefa de destruir o Um Anel sem ceder à tentação de usar o artefato contra o inimigo. Como escreveu Tolkien:

Seja como for, todo esse material diz respeito principalmente à Queda, à Mortalidade e à Máquina. [...] Essas duas [primeiras] condições (isoladas ou juntas) levarão ao desejo de Poder, para tornar a vontade mais rapidamente efetiva - e assim à [utilização da] Máquina (ou Magia). Com a última tenho em mente o uso de planos ou artíficios (aparelhos) externos ao invés do desenvolvimento dos poderes ou talentos interiores inerentes - ou mesmo o uso desses talentos com o motivo corrupto da dominação: de intimidar o mundo real ou coagir outras vontades. A Máquina é nossa forma moderna mais óbvia, embora mais intimamente relacionada com a Magia do que se costuma reconhecer.

[...] O Inimigo, em sucessivas formas, sempre se ocupa "naturalmente" da mera Dominação, sendo o Senhor da magia e das máquinas; mas o problema - de que esse mal aterrorizante pode, e surge, de uma raiz aparentemente boa, o desejo de beneficiar o mundo e os demais", rapidamente e de acordo com os próprios planos do benfeitor - é um motivo recorrente ${ }^{98}$.

A rica narrativa de $O$ Senhor dos Anéis, tal como ressaltado por Russell Kirk, é um constante apelo à defesa da "liberdade moral que distingue os homens de animais" "99. Existe uma relação de necessidade entre o conceito de imaginação moral e a defesa de liberdade interior (ou liberdade moral) do indivíduo, pois:

As estórias permeadas pela imaginação moral apresentam suas personagens como cria-

\footnotetext{
* Não do iniciador do Mal: a sua foi uma Queda subcriativa e, por isso, os Elfos (os representantes da subcriação por excelência) eram particularmente seus inimigos e o objeto especial de seu desejo e ódio - e abertos aos seus engodos. A Queda deles está na cobiça e (em menor grau) na deturpação de sua arte em poder. [Nota escrita pelo próprio Tolkien].

${ }^{98}$ TOLKIEN. As Cartas de J. R. R. Tolkien. p. 142-43.

${ }^{99}$ KIRK. Tolkien e a Verdade da Fantasia. p. 784.
}

turas dotadas de livre-arbítrio, logo a escolha entre o bem e o mal é a decorrência de ações voluntárias. A opção entre fazer o que é certo, mesmo contrariando a própria vontade e se sacrificando, ou seguir o caminho mais fácil, tentando manipular a realidade, é o que diferencia uma personagem boa de uma má. Assim como em O Senhor dos Anéis, em As Crônicas de Nárnia ou em Harry Potter, em Star Wars verificamos que as personagens não são vitimas das armadilhas do destino, mas são livres para escolher entre fazer o bem ou o mal ${ }^{100}$.

A liberdade moral é intrínseca à natureza do homem, sendo o sustentáculo das demais liberdades. É nesse sentido, que o padre argentino Roberto Irigaray, S.J., afirma:

Os homens são criados como seres livres, e a realização máxima dessa liberdade ocorre no tipo de atitude existencial que adotam diante de Deus. Tolkien ressalta que a resposta da criatura para Deus deve ser traduzida tanto como fidelidade ao desígnio da providência quanto ao seu autor (no caso do bem). A radical importância histórica das decisões morais tomadas pelos protagonistas de suas narrativas é enfatizada ao longo de toda a sub-criação tolkieniana ${ }^{101}$.

Em notas escritas em 1956 sobre a crítica de W. H. Auden ao livro O Retorno do Rei, o próprio Tolkien trata da temática com as seguintes palavras:

$\mathrm{Na}$ minha história não lido com o $\mathrm{Mal} \mathrm{Ab-}$ soluto. Não creio que haja tal coisa, uma vez que ela é Nula. Não creio, de qualquer modo, que qualquer "ser racional" seja completamente mau. Satã caiu. Em meu mito, Morgoth caiu antes da Criação do mundo físico. Na minha história, Sauron representa uma aproximação do completamente mau tão próximo quanto possível. Ele seguiu o caminho de todos os tiranos: começando

100 CATHARINO. A Imaginação Moral em Star Wars. p. 242.

101 IRIGARAY, S.J., Ricardo. Tolkien e a Fé Cristã. Trad. Márcia Xavier de Brito. COMMUNIO: Revista Internacional de Teologia e Cultura, v. 27, n. 2, p. 49194. Abr.-Jun. 2008. p. 492. 
bem, pelo menos no nível que, apesar de desejar ordenar todas as coisas de acordo com a sua própria sabedoria, ele no início ainda levava em consideração o bem-estar (econômico) de outros habitantes da Terra. Mas ele foi além dos tiranos humanos no orgulho e na ânsia por dominação, sendo em origem um espírito (angelical) imortal*. Em O Senhor dos Anéis o conflito não é basicamente sobre "liberdade", embora ela esteja naturalmente envolvida. É sobre Deus e Seu direito único à honra divina. Os Eldar e os Númenorianos acreditavam n'O Único, o Deus verdadeiro, e consideravam a devoção a qualquer outra pessoa uma abominação. Sauron desejava ser um Rei-Deus, e assim era considerado por seus servidores ${ }^{\dagger}$; se tivesse sido vitorioso, ele teria exigido honras divinas de todas as criaturas racionais e poder temporal absoluto sobre o mundo inteiro ${ }^{102}$.

\section{III - As LIBERDADES NA Trilogia $O$ SENHOR dOS ANÉIS}

Russell Kirk enfatizou que a "a trombeta de Tolkien nos desperta para as verdades de que o mundo é, necessariamente, um lugar de esforço $e$ de que nenhum destino é pior do que uma débil segurança"103. Ao longo do século XX, nenhuma corrente de pensamento social, político e econômico ressaltou de forma tão acentuada

* Do mesmo gênero de Gandalf e Saruman, mas de uma ordem muito mais elevada. [Nota do próprio Tolkien].

+ Por uma traição tripla: 1. Por causa de sua admiração pela Força, tornara-se um seguidor de Morgoth e caiu com ele nas profundezas do mal, tornando-se seu principal agente na Terra Média. 2. Quando Morgoth foi derrotado pelos Valar, ele renunciou sua lealdade, mas apenas por medo; ele não se apresentou aos Valar ou suplicou por perdão, e permaneceu na Terra Média. 3. Quando ele descobriu o quanto seu conhecimento era admirado por todas as outras criaturas racionais e o quão fácil era influenciá-las, seu orgulho tornou-se sem limites. Ao final da Segunda Era, assumira a posição de representante de Morgoth. Ao final da Rerceira Era (embora na verdade muito mais fraco do que antes), afirmava ser Morgoth retornado. [Nota de Tolkien].

102 TOLKIEN. As Cartas de J. R. R. Tolkien. p. 233-34. ${ }^{103}$ KIRK. Tolkien e a Verdade da Fantasia. p. 784. a importância da liberdade nos diferentes âmbitos da ação humana e os riscos apresentados pelas promessas de segurança oferecidas pelo poder governamental quanto a Escola Austríca de Economia. Em 1949, Ludwig von Mises escreveu que "atualmente, as quimeras mais populares são a estabilização e a segurança"104. Seguindo a mesma linha de raciocínio, Murray N. Rothbard alertou, em 1970, que "toda ação, portanto, encerra um risco", destacando que "este risco não pode ser eliminado"105. Nas palavras de Mises, "não há neste mundo nada que se possa chamar de estabilidade ou segurança e nenhum esforço humano será capaz de criá-las" ${ }^{\prime 106}$. A imperfectibilidade ontológica das criaturas e os limites gnosiológicos do conhecimento acerca dos fenômenos externos à nossa vontade, principalmente àqueles que envolvem a decisão de outras pessoas, tornam irrealizáveis todos os planos humanos em busca de uma verdadeira segurança, pois, como argumenta Mises:

No mundo real, o agente homem defronta-se com o fato de que seu semelhante age por conta própria. A necessidade de ajustar suas ações às dos outros faz dele um especulador, para quem sucesso e fracasso dependem de sua maior ou menor habilidade em compreender o futuro. Toda ação é uma especulação. No curso da vida humana não há estabilidade e, consequentemente, não há segurança ${ }^{107}$.

$\mathrm{Na}$ modernidade, especialmente ao longo do século $\mathrm{XX}$, uma das falácias utópicas mais perigosas, disseminada por ideólogos de diferentes filiações teóricas, é a noção de que a redução das liberdades individuais em favor da ampliação do poder governamental sobre

${ }^{104}$ MISES, Ludwig von. Ação Humana: Um Tratado de Economia. Trad. Donald Stewart Jr. São Paulo: Instituto Ludwig von Mises Brasil, 3ª Ed., 2010. p. 101.

105 ROTHBARD, Murray N. Governo e Mercado: A Economia da Intervenção Estatal. Trad. Márcia Xavier de Brito e Alessandra Lass. São Paulo: Instituto Ludwig von Mises Brasil, 2012. p. 233.

${ }^{106}$ MISES. Ação Humana. p. 278.

${ }^{107}$ Ibidem. p. 147. 
a sociedade, principalmente em atividades de regulamentação das atividades econômicas, criaria um ambiente de estabilidade e de segurança. Tal crescimento da esfera estatal em nome da segurança social assemelha-se à promessa diabólica de Sauron na saga $O$ Senhor dos Anéis, que ofereceu seu conhecimento aos Elfos de Eregion para forjarem os "Anéis de Poder", com o benevolente propósito de retardar a decadência e preservar as boas coisas que são desejadas ou amadas, garantindo a estabilidade e a segurança contra a mudança, "vista como uma coisa lamentável"; no entanto, tal "magia" ou "maquinário", necessariamente, é "um motivo facilmente corruptível ao mal, uma ânsia por dominação", pois, de acordo com o próprio Tolkien, "'poder' é uma palavra agourenta e sinistra em todos esses contos, exceto quando aplicada aos deuses" 108 .

A visão extremamente crítica de Tolkien sobre o "poder" temporal é a mesma sustentada ao longo da experiência histórica da civilização ocidental na Sagrada Escritura e nas obras de literatos, teólogos, filósofos, historiadores e economistas. Tanto nas obras literárias de ficção quanto nos relatos de escritores religiosos, o tentador costuma utilizar a oferta de poder temporal como meio de corromper a alma do homem. De acordo com as narrativas dos evangelhos de São Mateus (Mt 4, 8-9) e de São Lucas (Lc 4, 5-7), ao próprio Jesus Cristo foi oferecido por Satanás o poder sobre todos os reinos deste mundo. No universo fantástico criado por Tolkien, a sedução da criatura em busca do poder é um tema recorrente, que encontra sua melhor representação na própria ideia do Um Anel, criado por Sauron com o objetivo de controlar de forma absoluta todas as demais criaturas, de modo a tornar-se um Rei-Deus. A sedução pelo poder temporal é um dos maiores problemas morais a ser enfrentado, pois o desejo e a busca pelo poder de controlar a existência dos semelhantes é uma das marcas distintivas do pecado original na natureza humana, que afeta, principalmente, os chamados grandes

\footnotetext{
${ }^{108}$ TOLKIEN. As Cartas de J. R. R. Tolkien. p. 148.
}

homens. Em uma carta, de 5 de abril de 1887, para o bispo anglicano Mandell Creighton (1843-1901), o historiador católico inglês John Emerich Edward Dalberg-Acton (1834-1902), Lorde Acton, aborda o problema com as seguintes palavras:

Não posso aceitar vosso critério de que devemos julgar o papa e o rei de modo diverso dos demais homens, com a presunção favorável de que não erram. Se há qualquer presunção, é no sentido oposto, contra os detentores do poder, que aumenta à medida que avulta o poder. A responsabilidade histórica compensa a carência de responsabilidade jurídica. O poder tende a corromper, e o poder absoluto corrompe absolutamente. Grandes homens são quase sempre os homens maus, mesmo quando exercem influência e não autoridade, e, ainda mais, quando se acrescenta a tendência ou a certeza de corrupção pela autoridade. Não há pior heresia do que o cargo santificar seu detentor ${ }^{109}$.

Mesmo não sendo o ponto central da obra, o problema do poder ocupa um espaço de destaque em $O$ Senhor dos Anéis, criando uma dinâmica entre a narrativa heróica e as estruturas de poder, possibilitanto algumas reflexões filosóficas sobre a forma que o poder interage com o conhecimento, a linguagem e a vida comunitária ${ }^{110}$. Na saga tolkieniana, a utilização do poder temporal contra a liberdade individual, ainda que tendo em mira uma causa nobre, leva necessariamente à corrupção da criatura, tal como fica expresso no diálogo entre Boromir e Frodo, em que o primeiro tenta convencer o segundo a utilizar o Um Anel para defender a cidade de Minas Tirith, capital

109 ACTON, John Emerich Edward Dalberg-. ActonCreighton Correspondence. In: Selected Writings of Lord Acton - Volume II: Essays in the Study and Writing of History. Ed. J. Rufus Fears. Indianapolis: Liberty Classics, 1986. p. 383.

${ }^{110}$ Uma reflexão sistematica sobre esses temas aparece na seguinte obra: CHANCE, Jane. Lord of the Rings: The Mythology of Power. Lexington: The University Press of Kentucky, 2001. 
do reino de Gondor, contra os ataques das forças agressoras de Mordor:

De repente, Boromir se aproximou e sentou-se ao lado dele. - Tem certeza de que não está sofrendo sem necessidade? - disse ele. Quero ajuda-lo. Você precisa de um conselho nessa difícil escolha. Aceita o meu?

- Acho que já sei que tipo de conselho você vai me oferecer, Boromir - disse Frodo. - E eu poderia considera-lo sábio se não fosse pela advertência do meu coração.

- Advertência? Advertência contra quê? disse Boromir abruptamente.

- Contra a demora. Contra o caminho que parece mais fácil. Contra a recusa do fardo que é colocado sobre meus ombros. Contra... Bem, é melhor que eu diga, contra a confiança na força e na sinceridade dos homens.

- Apesar disso, essa força vem por muito tempo protegendo vocês em seu pequeno país, embora não soubessem disso.

- Não duvido do valor de seu povo. Mas o mundo está mudando. As muralhas de Minas Tirith podem ser fortes, mas não são fortes o suficiente. Se não aguentarem o que pode acontecer?

- Pereceremos na batalha, valorosamente. Mas ainda existe esperança de que elas aguentem.

- Não há esperaça enquanto o Anel continuar existindo - disse Frodo.

- Ah! O Anel - disse Boromir, com os olhos faiscando. - O Anel! Não é um destino estranho nós sofrermos tanto medo e dúvida por uma coisa tão pequena? Uma coisa tão pequena! E eu o vi apenas por um instante na casa de Elrond. Poderia vê-lo um pouco outra vez?

Frodo levantou os olhos. De repente o seu coração gelou. Captou o brilho estranho no olhar de Boromir, apesar de seu rosto ainda se manter gentil e amigável. - É melhor que fique escondido - respondeu ele.

- Como quiser. Não me preocupo - disse Boromir. - Mas não posso nem falar dele? Pois você parece estar pensando só no poder do Anel nas mãos do Inimigo: em seus usos maléficos, e não nos bons. O mundo está mudando, você diz. Minas Tirith vai perecer, se o Anel perdurar. Mas por quê? Certamente seria assim se o anel tivesse com o Inimigo. Mas por quê, se estivesse conosco?
- Você estava no Conselho - respondeu Frodo. - Porque não podemos usá-lo, e porque o que é feito com ele se transforma em malefício $^{111}$.

O valoroso guerreiro Boromir não era um homem mau que pretendia usar o poder para benefício próprio, no entanto, foi seduzido pela ideia de fazer o bem por intermédio do Um Anel, sendo salvo da corrupção apenas pelo arrependimento e pelo sacrifício. De acordo com a narrativa tolkieniana, o caminho para a verdadeira sabedoria reside em não se corromper pelo poder, tal como ilustrado pela recusa tanto de Gandalf ${ }^{112}$ quanto de Galadriel ${ }^{113} \mathrm{em}$ possuir o Um Anel. O dese-

111 TOLKIEN. A Sociedade do Anel. p. 423-24.

112 Ao receber, por ser sábio e poderoso, a oferta de Frodo para que ficasse com o Um Anel, Gandalf recusa tal proposta com as seguintes palavras: “-Não! - gritou Gandalf, levantando-se de repente. - Com esse poder eu teria um poder grande e terrível demais. E comigo o Anel ganharia uma força ainda mais fatal - Seus olhos brilharam e seu rosto se acendeu como se estivesse iluminado por dentro. - Não me tente! Pois eu não quero ficar como o próprio Senhor do Escuro. Mas o caminho do Anel até meu coração é através da piedade, piedade pela fraqueza e pelo desejo de ter forças para fazer o bem. Não me tente! Não ouso toma-lo, nem mesmo, para mantê-lo a salvo, sem uso. O desejo de controlá-lo seria grande demais para as minhas forças. E vou precisar delas. Grandes perigos me esperam". (Ibidem. p. 63).

113 Não aguentando mais o fardo de ser o portador do Anel e por ter constatado que a Senhora dos elfos de Lothlórien era sábia, destemida e gentil, Frodo decidiu entregar-lhe o objeto. Diante dessa oferta, Galadriel:

[...] riu, com uma risada súbita e cristalina. - Sábia, a Senhora Galadriel pode ser - disse ela -, mas aqui ela encontrou alguém que está à sua altura em cortesia. De modo muito gentil você se vingou do teste que apliquei ao seu coração em nosso primeiro encontro. Agora comeá a enxergar com olhos agudos. Não vou negar que meu coração desejou muito pedir o que está oferecendo. Por muitos longos anos, pensei o que faria, caso o Grande Anel me chegasse às mãos, e veja! Ele está agora ao meu alcance. O mal que foi concebido há muito tempo continua agindo de muitas maneiras, quer o próprio Sauron seja ou não derrotado. Não teria sido uma ação nobre a ser creditada ao Anel dele, se eu o tivesse tomado à força ou ameaçado o meu hóspede?

- E agora finalmente ele chega. Você me oferece o Anel livremente! No lugar do Senhor do Escuro, 
jo pela posse do Um Anel, mesmo que visando inicialmente um fim benéfico, foi o fator responsável pela "queda" de Saruman, cuja concupiscência o levou a buscar desenfreadamente o conhecimento, tornando-o orgulhoso, fazendo-o ceder à vontade de poder e ao anseio de dirigir o destino de outros seres livres, além de partir a própria natureza, de invejar Gandalf, de desdenhar de Radagast, e, finalmente, de trair a causa que jurou defender, vindo a se transformar em um perfeito servo do Inimigo que originalmente desejava combater. Durante a reunião do Conselho de Elrond, em Valfenda, Gandalf narrou a traição de Saruman, relatando o modo como este tentou seduzi-lo e o aprisionara no pináculo da Torre de Orthanc, em Isengard:

[...] - [Saruman] Pôs-se de pé e então começou a declamar, como se estivesse fazendo um discurso longamente ensaiado. “Os Dias Antigos se foram. Os Dias Médios estão passando. Os Dias Mais Jovens estão começando. A época dos elfos se acabou, mas o nosso tempo está chegando: o mundo dos homens, que devemos governar. Mas precisamos de poder, poder para ordenar todas as coisas como queremos, para o bem que apenas os sábios podem enxergar".

- "E ouça bem, Gandalf, meu velho amigo e ajudante", disse ele, vindo em minha direção e falando agora com uma voz mais suave. "Eu disse nós, pois poderá ser nós, se quiser se unir a mim. Um novo Poder se

você coloca uma Rainha. E não serei escura, mas bela e terrível como a Manhã e a Noite! Bela como o Mar e o Sol e a Neve sobre a Montanha! Aterrorizante como a Tempestade e o Trovão! Mais forte que os fundamentos da terra. Todos deverão me amar e se desesperar!

Levandou a mão e do anel que usava emanou uma grande luz que iluminou a ela somente, deixando todo o resto escuro. Ficou diante de Frodo e parecia agora de uma altura incalculável, e de uma beleza insuportável, terrível e digna de adoração. Depois deixou a mão cair, e a luz se apagou; e de repente ela riu de novo e eis então que se encolheu: era uma mulher élfica frágil, vestida num trage simples e branco, cuja voz gentil era suave e triste.

- Passei pelo teste - disse ela. - Vou diminuir e me dirigir para o Oeste, continuando a ser Galadriel. (Ibidem. p. p. 388-89). levanta. Contra ele as velhas alianças e políticas não nos ajudarão em nada. Não há mais esperança nos elfos ou na agonizante Númenor. Esta então é uma escolha diante de você, diante de nós. Podemos nos unir a esse Poder. Seria uma sábia decisão. Gandalf. Existe esperança por esse caminho. A vitória dele se aproxima, e haverá recompensas para aqueles que o ajudarem. Enquanto o Poder crescer, os que se mostrarem seus amigos também crescerão; e os Sábios, como você e eu, poderão, com paciência, vir finalmente a governar seus rumos, e a controlá-lo. Podemos esperar nossa hora, podemos guardar o que pensamos em nossos corações, talvez deplorando as maldades feitas incidentalmente, mas aprovando o propósito final e mais alto: Conhecimento, Liderança, Ordem; todas as coisas que até agora lutamos em vão para conseguir, mais atrapalhados que ajudados por nossos amigos fracos e inúteis. Não precisaria haver, e não haveria, qualquer mudança em nossos propósitos, só em nossos meios".

- "Saruman", disse eu. "Já escutei discursos desse tipo antes, mas apenas das bocas dos emissários enviados de Mordor para enganar os ignorantes. Não posso crer que tenha me trazido de tão longe só para cansar os meus ouvidos".

- Lançou-me um olhar oblíquo, e parou um pouco, pensando. "Bem, vejo que este caminho sábio não funciona no seu caso", disse ele. "Ainda não? Não se uma maneira melhor pudesse ser criada?"

- Aproximou-se e colocou a mão longa sobre o meu braço. "E por que não Gandalf?", sussurrou ele. "Por que não o Anel Governante? Se pudéssemos dominá-lo, então o Poder passaria para nós. Foi por isso, na verdade, que o troxe até aqui. Pois tenho muitos olhos trabalhando para mim, e acredito que você sabe agora onde esse objeto precioso estã. Não é verdade? Ou então, por que os Nove querem saber sobre o Condado, e qual é o interesse que você tem lá?" E enquanto dizia isso, um desejo ardente que ele não podia ocultar brilhava em seus olhos. - "Saruman", disse eu, afastando-me dele, "só uma mão de cada vez pode governar o Anel, e você sabe disso muito bem; então não se preocupe em dizer nós! Mas eu não o 
daria a você, nunca! Não daria nem notícias dele, agora que sei o que se passa na sua cabeça. Você foi o chefe do Conselho, mas desmascarou-se a si mesmo finalmente. Bem, as opções são, ao que parece, submeter-me a Sauron ou a você. Não escolho nenhuma das duas. Não tem outras para oferecer?

- Agora ele estava frio e perigoso. "Sim", disse ele. "Não esperava que demostrasse sabedoria, mesmo para sua própria vantagem; mas dei-lhe a chance de me ajudar por bem, e de se poupar de muitos problemas e sofrimentos. A terceira opção é ficar aqui até o fim".

- "Até o fim?"

- "Até que me revela onde o Um Anel pode ser encontrado. Posso procurar meios de persuadi-lo. Ou até que seja encontrado à sua revelia, e o Governante possa se voltar para questões mais leves: encontrar, vamos dizer, uma recompensa adequada para a sua falta de colaboração e a insolência de Gandalf, o Cinzento".

- "Essa pode acabar não sendo uma das questões mais leves", disse eu. Ele riu de mim, pois minhas palavras eram vazias, $\mathrm{e}$ ele sabia disso ${ }^{114}$.

Em nosso mundo, precisamos evitar os ditames diabólicos do poder, principalmente, a tentativa ingênua de usar a máquina estatal para implantar medidas aparentemente benéficas para a comunidade, mas, que, na prática, terão como único resultado a restrição da liberdade individual em nome da segurança, da paz, do bem-comum, da moralidade, da prosperidade ou de qualquer outro princípio louvável. $O$ verdadeiro defensor da liberdade não deve ceder às tentações do poder. Ludwig von Mises e Russell Kirk conheciam os riscos inerentes à tentativa de utilizar do poder governamental como meio de implementar a causa da liberdade. Russell Kirk foi convidado tanto pelo presidente Richard Nixon (1913-1994) quanto pelo presidente Ronald Reagan (1911-2004) para assumir postos na administração pública federal norte-americana, no entanto, decli-

${ }^{114}$ Ibidem. p. 274-75. nou de tais propostas dizendo ironicamente para o primeiro que "poderia ter tido esse tipo de cargo quando tinha trinta anos, se desejasse", e brincando com o segundo afirmou: "como deves odiar-me para tentar transformar-me num burocrata"115. Em uma festa na residência do economista Leonard E. Read (1898-1983), na década de 1940, Ludwig von Mises foi questionado por um dos convidados sobre o que faria na hipótese de ser nomeado ditador dos Estados Unidos, gozando da possibilidade de impor as medidas que desejasse. A resposta imediata do economista austríaco foi: "Eu renunciaria!"116. Como sabiamente alertou J. R. R. Tolkien: "você não pode enfrentar o Inimigo com o Anel dele sem se tornar o Inimigo"117. Em 1927, o problema foi descrito por Mises com as seguintes palavras:

Verificamos que, ao abrirmos mão do princípio de que o Estado não deve interferir em quaisquer questões que tocam o modo de vida do indivíduo, terminamos por regulá-lo e restringi-lo aos mínimos detalhes. Abole-se a liberdade pessoal do indivíduo! Ele se torna um escravo da comunidade, obrigado a obedecer aos ditados da maioria. Não é necessário divagar sobre as maneiras pelas quais tais poderes poderiam ser utilizados até ao abuso por autoridades malévolas. $\mathrm{O}$ exercício de poderes desse tipo, mesmo por homens imbuídos das melhores intenções, necessariamente, reduziria o mundo a um cemitério do espírito ${ }^{118}$.

${ }^{115}$ KIRK, Russell. The Sword of Imagination: Memoirs of a Half-Century of Literary Conflict. Grand Rapids, William B. Eerdmans Publishing Company, 1995. p. 435.

${ }^{116}$ HÜLSMANN, Jörg Guido. Mises: The Last Knight of Liberalism. Alburn: Ludwig von Mises Institute, 2007. p. 824. Citado, originalmente, em: SENNHOLZ, Mary. Leonard E. Read: Philosopher of Freedom. Irvington-on Hudson: Foundation for Economic Education, 1993. p. 145.

${ }^{117}$ TOLKIEN. As Cartas de J. R. R. Tolkien. p. 95.

118 MISES, Ludwig von. Liberalismo: Segundo a Tradição Clássica. Trad. Haydn Coutinho Pimenta. São Paulo: Instituto Ludwig von Mises Brasil, 2 ${ }^{a}$ Ed., 2010. p. 79. 
Tanto no universo ficcional tolkieniano quanto no mundo em que vivemos há, de um lado, um conflito inerente entre os anseios por segurança e estabilidade e, por outro lado, as necessidades da liberdade individual que estão associadas às mudanças naturais intrínsecas ao fluxo dos acontecimentos históricos. Tal problema é explicado por Mises da seguinte maneira:

A vaga noção de segurança social que os doutrinadores do Estado provedor têm em mente quando denunciam a insegurança diz respeito a algo parecido com uma garantia de um padrão de vida que deveria ser assegurado a todos os membros da sociedade, qualquer que tenha sido o seu merecimento. Segurança, nesse sentido - afirmam os apologistas de épocas passadas - era o que existia no regime social da Idade Média. Não há necessidade de se aprofundar o exame dessas afirmativas. A situação real, mesmo no caso do tão decantado século XIII, era diferente do quadro ideal pintado pela filosofia escolástica; os esquemas desse tipo representavam uma descrição das condições como deveriam ser e não como eram na realidade.

Mas mesmo essas descrições utópicas dos filósofos e teólogos não deixavam de se referir à existência de uma numerosa classe de mendigos miseráveis, que dependiam inteiramente das esmolas que thes eram dadas pelos ricos. Não é essa exatamente a ideia de segurança social que se tem em mente hoje em dia ao se empregar esse termo.

O conceito de segurança que os assalariados e os pequenos agricultores postulam atualmente coincide com o conceito de estabilidade mantido pelos capitalistas. Da mesma forma que os capitalistas querem usufruir permanentemente uma renda que não fique sujeita às vicissitudes das mutáveis condições humanas, os assalariados e os pequenos agricultores também querem que suas rendas não fiquem na dependência do mercado. Ambos os grupos querem proteger-se do fluxo dos acontecimentos históricos. Nenhuma nova ocorrência deveria afetar negativamente a sua própria posição; por outro lado, evidentemente, nada têm a objetar a uma melhoria do seu bem-estar material.
[‥] É claro que os desejos dessas pessoas só poderiam ser atendidos num mundo perfeitamente estagnado ${ }^{119}$.

Um dos acontecimentos mais dramáticos do século XX, tal como descrito no livro O Caminho da Servidão, em 1944, por F. A. Hayek, foi "a mudança estrutural da sociedade, implícita na vitória do ideal de segurança sobre $o$ de independência"120. Essa transformação reduziu drasticamente as liberdades individuais nas democracias ocidentais, fazendo, nas palavras de Tolkien, que a maioria dos "adoradores do Deus-Estado" expandam o domínio governamental sobre a sociedade e vivam "em paz e abundância e em estima e confiança mútuas"121. Hayek relata o problema da seguinte maneira:

Numa sociedade em que o indivíduo conquista posição e honras quase exclusivamente em função de ser um servidor assalariado do governo; em que o cumprimento do dever prescrito é considerado mais louvável do que a escolha do próprio campo de atividade; em que todas as ocupações que não conferem um lugar na hierarquia oficial ou o direito a um rendimento fixo são julgadas inferiores e até certo ponto aviltantes - seria demais esperar que a maioria prefira por muito tempo a liberdade à segurança. E quando só se pode optar entre a segurança numa posição de dependência e a extrema precariedade numa situação em que tanto o fracasso como o êxito são desprezados, poucos resistirão à tentação da segurança ao preço da liberdade. Tendo-se chegado a esse ponto, a liberdade torna-se quase um objeto de escárnio, pois só pode ser alcançada com o sacrifício de grande parte das boas coisas da vida. Nessas condições, não surpreende que um número cada vez maior de pessoas se convença de que sem segurança econômica a liberdade

\footnotetext{
${ }^{119}$ Idem. Ação Humana. p. 960-61.

${ }^{120}$ HAYEK, F. A. O Caminho da Servidão. Trad. Anna Maria Capovilla, José Ítalo Stelle e Liane de Morais Ribeiro. São Paulo: Instituto Ludwig von Mises Brasil, 6⿳a Ed., 2010. p. 136.

${ }^{121}$ TOLKIEN. As Cartas de J. R. R. Tolkien. p. 234.
} 
"não vale a pena" e se disponha a sacrificar esta em troca daquela ${ }^{122}$.

A grande tragédia, no entanto, é o fato, notado por Mises, de que "existem, possivelmente, indivíduos, grupos de indivíduos e mesmo povos inteiros ou raças que apreciem a proteção $e$ a segurança proporcionadas pela servidão"123. Nas palavras de Rothbard, "muitas pessoas, mesmo sabendo que a escravidão ou a sujeição a um ditador não pode dar segurança absoluta, ainda desejarão confiar em tais senhores"124. Tais indivíduos se assemelham aos homens do "Sul" e do "Leste", na narrativa de $O$ Senhor dos Anéis, que, por medo ou por idolatria ao falso Rei-Deus, se deixaram subjugar pela vontade de Sauron, servindo ao mal e lutando na Guerra do Anel ao lado do Inimigo contra os "Povos Livres do Oeste". Contudo, tal como, há mais de trezentos anos, conclamou Benjamin Franklin (17061790): "aqueles que abrem mão da liberdade essencial por um pouco de segurança temporária não merecem nem liberdade nem segurança" ${ }^{\prime 25}$.

Ainda que a luta contra uma falsa e confortável segurança na servidão em prol da preservação das diferentes formas de liberdade não seja o tema central de $O$ Senhor dos Anéis, a saga pode ser tomada como um valioso modelo de imaginação moral para "a Causa daqueles que se opõem agora ao Deus-Estado e ao Oficial Disso ou Daquilo como seu Sumo-Sacerdote"126. “O fato de Tolkien enfatizar tantas escolhas é significativo", pois, de acordo com Matthew Dickerson, "existe nos trabalhos de Tolkien um espaço proeminente dado para a escolha e para a liberdade (de Homens, Ananos, Elfos e Hobbits), e, também, para a prima da liberdade: a criatividade"127.

${ }^{122}$ HAYEK. O Caminho da Servidão. p. 136-37.

${ }^{123}$ MISES. Ação Humana. p. 717-18.

${ }^{124}$ ROTHBARD. Governo e Mercado. p. 235.

125 FRANKLIN, Benjamin \& FRANKLIN, William Temple. Memoirs of Life and Writings of Benjamin Franklin - Volume I. London: Henry Colburn, 1818. p. 270.

${ }^{126}$ TOLKIEN. As Cartas de J. R. R. Tolkien. p. 234.

${ }^{127}$ DICKERSON, Matthew. Following Gandalf: Epic Battles and Moral Victory in The Lord of the Rings. Grand Rapids: Brazos Press, 2004. p. 83.
Tal ênfase da narrativa tolkieniana nas interrelações entre escolhas individuais, liberdade e criatividade permite que a saga $\mathrm{O} S e-$ nhor dos Anéis seja analisada à luz do núcleo fundamental que caracteriza o pesamento da Escola Austríaca de Economia. A defesa da liberdade, bem como as análises sociais e econômicas, da Escola Austríaca de Economia são sustentadas por uma "tríade básica" ou "núcleo fundamental", constituído pelos conceitos de "ação humana" e de "tempo dinâmico" e pela hipótese dos "limites do conhecimento humano"128.

Os pensadores da Escola Austríaca entendem que os problemas estudados pela Ciência Econômica são parte integrante de uma "teoria geral da ação humana, a praxeologia", visto que o exame das economias de mercado, isto é, as relações de troca e o sistema de formação dos preços, chamada de "cataláxia", envolve necessariamente "atos de escolha"129. Na perspectiva praxeológica, tal como elaborada por Ludwig von Mises, "ação humana é comportamento propositado", sendo fruto da "vontade posta em funcionamento", que é "transformada em força motriz" para "alcançar fins objetivos", constituindo, assim, "a significativa resposta do ego aos estímulos e às condições do seu meio", ou seja, a ação humana "é o ajustamento consciente ao estado do universo que lhe determina a vida"130. De acordo com a praxeologia, a ação humana não é uma mera manifestação de preferências individuais subjetivas, mas um dado irredutível da natureza humana, pois, ao longo de toda a existência neste mundo, os indivíduos são necessariamente compelidos a tomar decisões que envolvem atos pessoais deliberados de escolha que sempre implicam em obter ou renunciar por fins alternativos diante de meios escassos, manifestos no livre exercício da vontade com o objetivo de substituir uma situação menos satisfatória por outra,

\footnotetext{
128 IORIO, Ubiratan Jorge. Ação, Tempo e Conhecimento: A Escola Austríaca de Economia. São Paulo: Instituto Ludwig von Mises Brasil, 2011. p. 17-19.

${ }^{129}$ MISES. Ação Humana. p. 23-24.

${ }^{130}$ Ibidem. p. 36.
} 
aparente ou real, que seja mais satisfatória, a partir de uma visão racional sobre causas e efeitos ${ }^{131}$.

A trama de O Senhor dos Anéis não é construída a partir de uma concepção fatalista da realidade, mas, ao contrário, está fundamentada na livre escolha das diversas personagens. Em vários momentos da narrativa, diferentes personagens são postas diante de situações que exigem o exercício deliberado da capacidade praxeológica de tomar decisões acerca do rumo da ação que deve ser seguido. A liberdade de escolha fica explícita nas palavras do elfo Legolas para o anão Gimli, quando consola o amigo dizendo: " $-[. .$.$] considero$ você um abençoado, Gimli, filho de Glóin: pois sua perda você sofre de livre e espontânea vontade, $e$ poderia ter escolhido outro caminho. Mas não abandonou seus companheiros, [...]"132. De modo semelhante, em As Duas Torres, tal liberdade de escolher o rumo da ação, associada à incerteza, é ressaltada pelo dialógo entre Sam e Frodo, quando, num dos momentos mais difíceis da viagem para destruir o Um Anel, são guiados pela criatura Gollum na subida das escadarias de Crith Ungol em direção à Mordor, quando profunciam as seguintes palavras:

- Não gosto de nada por aqui - disse Frodo -, pedra ou poço, água ou osso. Terra, ar e água, tudo parece amaldiçoado. Mas nessa direção vai nossa trilha.

- É, é isso mesmo - disse Sam. - E de modo algum estaríamos aqui se estivéssemos mais bem informados antes de partir. Mas suponho que seja sempre assim. Os feitos corajosos das velhas canções e histórias, Sr. Frodo: aventuras, como as que eu as costumava chamar. Costumava pensar que eram coisas à procura das quais as pessoas maravilhosas das histórias saíam, porque as queriam, porque eram excitantes e a vida era um pouco enfadonha, um tipo de esporte, como se poderia dizer. Mas não foi assim com as histórias que realmente importam, ou aquelas que ficam na memória. As pessoas parecem

\footnotetext{
${ }^{131}$ Ibidem. p. 36-55.

${ }^{132}$ TOLKIEN. A Sociedade do Anel. p. 403.
}

ter tido apenas embarcado nelas, geralmente - seus caminhos apontavam naquela direção, como se diz. Mas acho que eles tiveram um monte de oportunidades, como nós, de dar as costas, apenas não o fizeram. [...] $]^{133}$.

Um dos principais exemplos desse livre exercício da vontade que se transforma numa ação deliberada visando à eliminação de um estado de desconforto está na própria decisão anterior tomada por Frodo na reunião do Conselho Elrond, ocasião em que foi debatido qual destino deveria ser dado ao Um Anel. Nessa passagem de A Sociedade do Anel, o pequeno Hobbit surpreende a todos ao decidir livremente seguir de Valfenda para Mordor com o objetivo de destruir o Um Anel nas chamas da Montanha da Perdição, o que levou o mestre elfo Elrond a tratar das escolhas de Frodo afirmando:

- Se entendo bem tudo o que foi dito - disse ele -, penso que essa tarefa é destinada a você, Frodo; e que se você não achar o caminho ninguém saberá. É chegada a hora do povo do Condado, quando deve se levantar de seus campos pacíficos para abalar as torres dos Grandes. Quem entre todos os Sábios, poderia prever isto? $\mathrm{Ou}$, se são mesmo sábios, por que deveriam esperar sabê-lo, até que a hora chegasse?

- Mas o fardo é pesado. Tão pesado que ninguém poderia impô-lo a outra pessoa. Não o imponho a você. Mas se o toma livremente, direi que sua escolha foi acertada $[\ldots]^{134}$.

Além da importância da livre ação de Frodo, o portador do Anel, as palavras de mestre Elrond tocam em dois outros elementos fundamentais da tríade básica da Escola Austríca, a questão do "tempo" e a da "incerteza". Diferente dos inúmeros sistemas lógicos que buscam explicar a realidade humana, o sistema praxeológico pressupõe as categorias de tempo e de causalidade. Por não vivermos num mundo estagnado, a própria noção de tempo é uma categoria paxeológica, fazendo

\footnotetext{
${ }^{133}$ Idem. As Duas Torres. p. 330.

${ }^{134}$ Idem. A Sociedade do Anel. p. 286.
} 
que as diversas mudanças experimendas pelo agente homem ao longo da existência impliquem na noção de sequência temporal, sempre envolvendo os conceitos de anterioridade e consequência nos raciocínios praxeológicos, bem como a noção de irreversibilidade dos acontecimentos, segundo a qual a passagem do tempo sempre acarreta numa evolução criativa, que implica em alterações imprevisíveis. Sobre a necessária relação existente entre o tempo e a ação humana, explica Mises:

A ação está sempre dirigida ao futuro; consiste essencial e necessariamente em planejar e agir com vistas a um futuro melhor. $\mathrm{O}$ objetivo da ação é sempre fazer com que as condições futuras sejam mais satisfatórias do que seriam sem sua interferência. $\mathrm{O}$ desconforto que impele um homem a agir é causado pela insatisfação com as condições futuras que provavelmente adviriam caso nada fosse feito para impedi-las. A ação só pode influir o futuro, nunca o presente, que a cada fração infinitesimal de segundo se transforma em passado. $\mathrm{O}$ homem adquire consciência do tempo, quando planeja converter uma situação presente menos satisfatória numa situação futura mais satisfatória ${ }^{135}$.

O conceito de "tempo real" ou "tempo dinâmico" ou "tempo subjetivo" adotado pela Escola Austríaca é distinto da concepção estática newtoniana, adotada por diferentes correntes de análise social e econômica, que entende o tempo como um simples eixo horizontal, sendo, assim, entendida como "fluxo permanente de novas experiências", tal como na perspectiva bergsoniana, fazendo que a ação humana, enquanto fenômeno temporal, não esteja no tempo, visto que é o próprio tempo, entendido como produto do conjunto de continuidade dinâmica, heterogeneidade e eficácia causal, pois "agindo, os indivíduos acumulam continuamente novas experiências, o que gera novos conhecimentos, o que, por sua vez, os leva a alterarem frequentemente seus planos e ações" ${ }^{\prime 136}$.

\footnotetext{
${ }^{135}$ MISES. Ação Humana. p. 134.

${ }^{136}$ IORIO. Ação, Tempo e Conhecimento. p. 18-19.
}

Tanto na perspectiva praxeológica defendida pela Escola Austríaca quanto na narrativa mitopoética de O Senhor dos Anéis, o presente não é visto como uma mera linha imaginária que separa o passado do futuro, mas é entendido como um instante real da duração, visto que "o momento presente oferece à ação oportunidades e tarefas para as quais, até então, era muito cedo e para as quais, daqui em diante, será muito tarde $^{\prime \prime 137}$. A vontade não é capaz de criar deliberadamente todas as pré-condições da ação, visto que o agente é livre para agir no tempo a partir de dados fragmentários sobre os acontecimentos do passado e de expectativas sobre o futuro, contudo, não conhece todas as variáveis que devem ser levadas em consideração, pois toda ação se dá necessariamente num ambiente de "incerteza", oriundo da própria limitação intrínseca ao conhecimento humano, que "contém sempre componentes de indeterminação e de imprevisibilidade, o que faz que todas as ações humanas produzam efeitos involuntários e que não podem ser calculados a priori"138. Hayek sustenta que "a justificativa da liberdade individual funda-se, principalmente, no reconhecimento da inevitável ignorância de todos os homens no que diz respeito à maioria dos fatores dos quais depende a realização dos nossos objetivos e do nosso bem-estar" ${ }^{\prime \prime 39}$. Dessa forma, é possível afirmar que:

Ao apresentar de forma clara e objetiva os limites do conhecimento humano e o funcionamento da economia como fruto da livre interação das vontades individuais de inúmeros agentes, com ênfase no papel do indivíduo na sociedade, os autores da Escola Austríaca demonstram não só a falibilidade do planejamento econômico governamental, mas também sua ineficiência e imoralidade, incongruente com a natureza humana ${ }^{140}$.

\footnotetext{
${ }^{137}$ MISES. Ação Humana. p. 135.

${ }^{138}$ IORIO. Ação, Tempo e Conhecimento. p. 19.
}

${ }^{139}$ HAYEK, F. A. Os Fundamentos da Liberdade. Intr. Henry Maksoud; Trad. Anna Maria Capovilla e José Ítalo Stelle. Brasília / São Paulo: Editora Universidade de Brasília/Visão, 1983. p. 26-27.

140 CATHARINO, Alex. A Economia do Bom Senso. Revista Vila Nova, Edição 02, mar/abr/mai 2012. p. 38. 
"A incerteza do futuro está implícita na própria noção de ação", de acordo com Mises, pois "se o homem pudesse conhecer o futuro, não teria que escolher e, portanto, não agiria. Seria um autômato, reagindo aos estímulos, sem vontade própria"141. Contudo, tal perspectiva praxeológica não é uma defesa ontológica da total liberdade humana, mas uma simples constatação do fato que os homens fazem escolhas e agem, ainda que com base num conhecimento limitado como uma mera resposta aos problemas que são postos diante dos agentes ao longo do tempo. Tal problemática é apresentada na narrativa tolkieniana no seguinte diálogo entre Frodo e Gandalf, quando ambos constatam que o anel "encontrado" por Bilbo e herdado por Frodo é o "Um Anel para todos governar" de Sauron e que o Senhor do Escuro retornara à sua antiga fortaleza na Torre Escura de Mordor, lançando, novamente, sua Sombra sobre a Terra-Média:

- Gostaria que isso não tivesse acontecido em minha época - disse Frodo.

- Eu também - disse Gandalf - Como todos os que vivem nestes tempos. Mas a decisão não é nossa. Tudo o que temos de decidir é o que fazer com o tempo que nos é dado [... $]^{142}$.

Tal capacidade de escolha do rumo da ação no presente, com vista à mudar a própria condição no futuro, diante de uma realidade externa condicionada por fatores incontroláveis pela vontade humana é a principal característica do conceito de liberdade defendido pela Escola Austríca, pois como explica Mises:

O conceito de liberdade só faz sentido na medida em que se refere às relações inter-humanas. Existiram autores que nos falaram de uma liberdade original - natural - de que o homem teria desfrutado num mítico estado natural anterior ao estabelecimento das relações sociais. Entretanto, esses indivíduos ou famílias econômica e mentalmente autossuficientes, vagando pelo mundo, só eram livres na medida em que não encontravam pela frente alguém mais forte.

\footnotetext{
${ }^{141}$ MISES. Ação Humana. p. 139.

142 TOLKIEN. A Sociedade do Anel. p. 52-53.
}

Na impiedosa competição biológica, o mais forte tinha sempre razão e o mais fraco não tinha outra escolha a não ser a submissão incondicional. O homem primitivo certamente não nasceu livre.

Somente no contexto de um sistema social é que se pode atribuir um significado à palavra liberdade. No sentido praxeológico, o termo liberdade refere-se à situação na qual um indivíduo tem a possibilidade de escolher entre modos de ação alternativos. Um homem é livre na medida em que lhe seja permitido escolher os seus fins e os meios a empregar para atingi-los. A liberdade de um homem é rigidamente restringida pelas leis da natureza, bem como pelas leis da praxeologia. Ele não pode pretender atingir fins incompatíveis entre si. Há prazeres que provocam efeitos determinados no funcionamento do corpo e da mente; se quiser desfrutá-los, terá de sofrer as consequências. Seria absurdo dizer que o homem não é livre porque não pode, digamos drogar-se, sem sofrer as inevitáveis consequências consideradas como altamente indesejáveis. Embora isso seja evidente para todas as pessoas de bom senso, esta evidência não é bem percebida em situações análogas sujeitas às leis da praxeologia.

O homem não pode, ao mesmo tempo, pretender ter as vantagens decorrentes da cooperação pacífica em sociedade, sob a égide da divisão do trabalho, e permitir-se uma conduta que inevitavelmente terminará por desintegrar a sociedade. Tem necessariamente de escolher entre o respeito a certas regras que tornam a vida em sociedade possível ou a pobreza e a insegurança, se preferir "viver perigosamente", num estado de guerra constante entre indivíduos independentes. Esta é uma lei tão exata na determinação do resultado da ação humana como um todo quanto são as leis da física ${ }^{143}$.

A principal concepção de liberdade defendida pelos autores da Escola Austríaca é a de Liberdade Individual ou Liberdade Pessoal, entendida por Hayek como "o estado no qual o homem não está sujeito à coerção pela vontade ar-

\footnotetext{
${ }^{143}$ MISES. Ação Humana. p. 339.
} 
bitrária de outrem"144, e definida por Rothbard como "ausência de invasão, de qualquer propriedade ou pessoa, exercida por outro homem"145. Nesse sentido, há uma relação necessária entre a liberdade individual e a livre inciativa na esfera econômica, pois, tal como explica Mises:

O grau de liberdade que os indivíduos podem usufruir num contexto de cooperação social depende da harmonização do ganho privado com o bem público. Na medida em que o indivíduo, ao perseguir o seu próprio bem-estar, aumenta também - ou pelo menos não prejudica - o bem-estar de seus semelhantes, as pessoas podem dedicar-se às suas atividades como bem entenderem, sem que isso coloque em risco a preservação da sociedade e os interesses alheios. Surge, assim, um reino de liberdade e de iniciativa individual, um reino no qual o homem é livre para escolher e para agir como bem entender. É a existência dessa liberdade - que os socialistas e intervencionistas desdenhosamente intitulam de "liberdade econômica" - que torna possível a existência de todas as demais liberdades compatíveis com a cooperação social sob o signo da divisão do trabalho. É a economia de mercado ou capitalismo, com seu corolário político (os marxistas diriam: com sua "superestrutura"), o governo representativo ${ }^{146}$.

Em termos filosóficos, a perspectiva adotada pela Escola Austríaca é a de Liberdade Negativa ("liberdade $\left.d e^{\prime \prime}\right)$, no sentido de indicar a ausência de interferência dentro da esfera de ação da pessoa, em contraposição à chamada Liberdade Positiva ("liberdade para"), entendida como o domínio efetivo sobre si próprio e sobre o meio externo ${ }^{147}$. De acordo

\footnotetext{
${ }^{144}$ HAYEK. Os Fundamentos da Liberdade. p. 4.

${ }^{145}$ ROTHBARD, Murray N. A Ética da Liberdade. Intr. Hans-Hermann Hoppe; Trad. Fernando Fiori Chiocca. São Paulo: Instituto Ludwig von Mises Brasil, 2ª Ed., 2010. p. 101.

${ }^{146}$ MISES. Ação Humana. p. 829.

${ }^{147} \mathrm{O}$ tema é debatido de forma mais sistemática, de um ponto de vista filosófico, por Sir Isaiah Berlin (19091997) na seguinte obra: BERLIN, Isaiah. Quatro Ensaios sobre a Liberdade. Trad. Wamberto Hudson Ferreira.
}

com Hayek, o conceito de liberdade individual não deve ser confundido com outros três significados distintos de liberdade, a saber:

$\left.1^{\circ}\right)$ A Liberdade Política, manifesta na "participação dos homens na escolha de seu governo, no processo legislativo e no controle da administração", sendo uma espécie de liberdade coletiva, compatível, em alguns casos, com a liberdade individual, que, no entanto, pode, em determinados contextos, entrar em conflito com a liberdade pessoal ao permitir a implantação da servidão individual aos poderes governamentais por intermédio do sistema democrático, visto que "um povo livre, nesse sentido, não é necessariamente um povo de homens livres, e não é preciso que o indivíduo compartilhe dessa liberdade coletiva para ser livere"148;

$2^{\circ}$ ) A Liberdade Interior ou Liberdade Moral, enquanto Livre Arbitrio ou "possibilidade de uma pessoa pautar-se em suas ações por sua própria vontade e consciência, por sua razão ou firme convicção e não por circunstâncias ou impulsos momentâneos", havendo inúmeros pontos comuns entre esse conceito e a noção de liberdade individual, sendo necessária uma diferenciação entre ambos apenas porque "a possibilidade de uma pessoa ser ou não capaz de uma escolha inteligente entre alternativas, ou de agir em conformidade com a resolução por ela tomada, é distinta da possibilidade de outras pessoas the imporem ou não seus desejos"149;

$3^{\circ}$ ) A Liberdade enquanto Poder, no sentido de possibilidade física para se fazer tudo o que quiser ou como capacidade se realizar todos os desejos, o que, além de uma ilusão, é incompatível tanto com a concepção de liberdade moral quanto com as concepções praxeológicas de liberdade. Tal concepção errônea conflita com as restrições físicas, morais e praxeológias da liberdade humana, fundamentando a ação livre não na ideia "nega-

Brasília: Editora Universidade de Brasília, 1981. No contexto da Escola Austríca o conceito de "liberdade negativa" é discutido de maneira mais ampla, em: HAYEK. Os Fundamentos da Liberdade. p. 3-18. Uma crítica aos modos como o conceito é utilizado tanto por Berlin quanto por Hayek é apresentada no seguinte texto: ROTHBARD. A Ética da Liberdade. p. 291-306.

${ }^{148}$ HAYEK. Os Fundamentos da Liberdade. p. 7-9.

${ }^{149}$ Ibidem. p. 9-10. 
tiva" de ausência de "coerção" injustificada, mas na concepção positiva de inexistência de qualquer forma de "restrição". De acordo com esse entendimento, é criada uma ideologia na qual "liberdade é poder, poder efetivo de fazer coisas específicas", difundindo a perigosa noção progressista de que "exigir liberdade é exigir poder"150.

O próprio estilo narratológico do gênero de Fantasia Mitopoética e a fundamentação de O Senhor dos Anéis na "Perspectiva Criacionista" e na "Perspectiva Ética" faz com que, ao longo de todo o texto, seja rejeitada a errônea noção de "Liberdade enquanto Poder", que pode ser vista como a própria forma de corrupção almejada pelo desejo de posse do Um Anel, que deverá ser combatida por intermédio da defesa das concepções de "Liberdade Interior", "Liberdade Individual" e "Liberdade Política". Tanto a narrativa de Tolkien quanto o pensamento da Escola Austríaca relacionam as verdadeiras formas de liberdade com a "responsabilidade" dos agentes individuais, que por não serem oniscientes deverão arcar com o resultado das próprias escolhas. "Vivemos em um mundo de imensuráveis e inevitáveis variedades de incertezas e de riscos", conforme ressaltado por Rothbard, fazendo, assim, que "em uma sociedade livre, com direitos individuais plenos, a assunção racional de riscos" seja "feita pelo indivíduo em relação a sua própria pessoa e a sua propriedade justamente adquirida"151. Nas palavras de Hayek:

Liberdade não apenas significa que o indivíduo tem a oportunidade e, ao mesmo tempo, a responsabilidade de escolher; também significa que deve arcar com as consequências de suas ações, pelas quais será louvado ou criticado. Liberdade e responsabilidade são inseparáveis. Uma sociedade livre não será viável nem poderá sustentar-se se seus membros não considerarem justo que cada indivíduo ocupe a posição conquistada por sua iniciativa e não a aceitarem como resultado desta. Embora possa oferecer apenas

\footnotetext{
${ }^{150}$ Ibidem. p. 10-12.

${ }^{151}$ ROTHBARD. A Ética da Liberdade. p. 317.
}

oportunidades ao indivíduo e o resultado da atividade deste dependa de inúmeras contingências, uma sociedade livre leva o indivíduo a concentrar seus esforços nas circunstâncias que ele pode controlar, como se somente estas constituíssem o êxito de suas ações. Como indivíduo terá a oportunidade de utilizar condições que somente ele conhece e como na grande maioria dos casos, ninguém mais poderá julgar se ele explorou essas condições da melhor maneira possível, presume-se que elas determinam o resultado de suas ações a não ser que o contrário seja óbvio ${ }^{152}$.

A narrativa de O Senhor dos Anéis está repleta de exemplos do uso responsável das liberdades interior, individual e política pelos heróis da Terra-Média na luta contra as agressões e tentativas de dominação perpetradas pelos inimigos. A vivência espiritual do catolicismo marcou profundamente o entendimento de Tolkien sobre a importância da liberdade humana como uma característica intrínseca à própria noção antropológica de "criatura racional, composta de alma e corpo" (I, ii, § 3ㅇ, 48), feita a "imagem e semelhança de Deus porque a alma humana é espiritual e racional, livre na sua ação" (I, ii, $\S 3$ 은 55), tal como exposta no Catecismo Maior de São Pio $X^{153}$, o terceiro catecismo da doutrina cristã, promulgado em 15 de abril de 1905. De acordo com esse documento do Magistério Romano, que foi a base doutrinária da catequese de Tolkien, "o homem é livre nas suas ações; $e$ cada qual sente, dentro de si mesmo, que pode fazer uma ação e deixar de fazê-la, ou fazer antes uma que outra" (I, ii, § 3o, 53). A concepção católica de liberdade interior, embasada na própria consciência, como fundamento ontológico da liberdade individual se assemelha a seguinde noção defendida por Rothbard:

O homem, através da introspecção de sua própria consciência, também descobre o fato natural primordial que é sua a sua li-

\footnotetext{
${ }^{152}$ HAYEK. Os Fundamentos da Liberdade. p. 76.

${ }^{153}$ Utilizamos aqui a seguinte edição do documento: Catecismo Maior de São Pio X. Campo Grande: Edições Santo Tomás, 2005.
} 
berdade: sua liberdade de escolher, sua liberdade de usar ou de não usar sua razão em qualquer assunto existente. Em resumo, a ocorrência natural de seu "livre arbítrio". Ele também verifica o fato natural do comando de sua mente sobre seu corpo e suas ações: ou seja, de sua propriedade natural sobre si mesmo ${ }^{154}$.

Tal liberdade de consciência é uma característica marcante da "Perspectiva Ética" adotada por Tolkien e manifestada em diversos momentos de toda a saga; como, por exemplo, nas já citadas recusas de Gandalf ${ }^{155} \mathrm{e}$ de Galadriel ${ }^{156} \mathrm{em}$ aceitar o Um Anel oferecido livremente por Frodo; bem como, no combate mortal entre Gandalf e o Balrog na Ponte de Khazad-dûm ${ }^{157}$; na resistência da donzela Éowyn, Senhora de Rohan, aos assédios e manipulações de Gríma Língua-de-cobra' ${ }^{158}$; na passagem em que Sam enfrenta Laracna com o Frasco de Galadriel e a espada élfica Ferroada ${ }^{159}$; na livre oferta de Pippin para servir ao regente Denethor em pagamento pelo sacríficio de Boromir ${ }^{160}$; na autorevelação de Aragorn para Sauron através do Palantír ${ }^{161}$; na resistência de Gandalf e Aragorn ao discurso falso e desesperançoso do mensageiro Boca de Sauron, o Tenente da Torre de Barad-dûr, antes da Batalha do Portão Negro ${ }^{162}$; na capacidade de Frodo perdoar Gollum após a destruição do Um Anel ${ }^{163}$; e, finalmente, na resignação de Frodo e de Sam ao encontrarem alegria, conforto e gratidão quando estavam prestes a serem consumidos pelas chamas da

${ }^{154}$ ROTHBARD. A Ética da Liberdade. p. 88.

${ }^{155}$ TOLKIEN. A Sociedade do Anel. p. 63.

${ }^{156}$ Ibidem. p. 388-89.

${ }^{157}$ Ibidem. p. 350-51; Idem. As Duas Torres. p. 99-100.

${ }^{158}$ Idem. As Duas Torres. p. 120, Idem. O Retorno do Rei. p. 45, 134-36.

${ }^{159}$ Idem. As Duas Torres. p. 349-51.

${ }^{160}$ Idem. O Retorno do Rei. p. 13-15.

${ }^{161}$ Ibidem. p. 40-41.

${ }^{162}$ Ibidem. p. 158-61.

${ }^{163}$ Ibidem. p. 223.
Montanha da Perdição ${ }^{164}$. A existência dessa liberdade interior é o que possibilita as ecolhas criativas das personagens de $O$ Senhor dos Anéis, que podem sucumbir diante do vício de tentar controlar a vontade alheia, representada pelo desejo de possuir o Um Anel, assumindo o caminho da corrupção pessoal, ou podem aceitar a postura heróica de lutar contra o mal, cultivando as virtudes da Fé, da Esperança, da Caridade, da Prudência, da Justiça, da Fortaleza, da Temperança, da Coragem, da Mansidão e, principalmente, da Humildade.

Um exemplo paradigmático dessa resistência moral, fundada na liberdade de consciência, é a diferença de postura entre Gandalf e Saruman diante da possibilidade de controlar o Um Anel. Em uma carta, escrita, provavelmente, em janeiro ou fevereiro de 1956, o próprio Tolkien explica esse importante aspecto com as seguintes palavras:

[...] Não há "personificação" do Criador em lugar algum nesta história ou na mitologia. Gandalf é uma pessoa "criada", embora possivelmente um espírito que existia antes no mundo físico. Sua função como um "mago" é a de um angelos ou mensageiro dos Valar ou Governantes: para auxiliar as criaturas racionais da Terra-média a resistirem a Sauron, um poder grande demais para elas sem auxílio. Mas uma vez que na concepção desta história e mitologia o Poder - quando domina ou procura dominar outras vontades e mentes (exceto pelo consentimento da razão destas) - é maligno, esses "magos" foram encarnados nas formas de vida da Terra-média, e desta forma sofriam as dores tanto da mente quanto do corpo. Também estavam envolvidos dessa maneira, pela mesma razão, no perigo dos encarnados: a possibilidade de "queda", de pecado, se preferir. A principal forma assumida por esse perigo era a impaciência, que levava ao desejo de forçar outros aos seus próprios fins benignos e assim, inevitavelmente, por fim ao mero desejo de tornar suas próprias vontades efetivas de qualquer modo. A esse mal Saruman sucumbiu. Gandalf não.

${ }^{164}$ Ibidem. p. 227-28. 
Contudo, a situação tornou-se tão pior com a queda de Saruman que os "bons" foram obrigados a esforços e sacrifícios maiores. Assim Gandalf enfrentou e sofreu a morte; e voltou ou foi enviado de volta, como ele diz, com seu poder aumentado. $[. . .]^{165}$.

Na saga O Senhor dos Anéis, a liberdade interior é a força moral que permite ao indivíduo trilhar o caminho do bem, não interferindo na livre vontade das outras criaturas racionais, que podem escolher livremente $o$ próprio modo de vida. Em toda a narrativa tolkieniana, as tentativas de interferência na liberdade individual ou na liberdade política de criaturas racionais e pacíficas são tomadas como um ato de opressão perpetrado por um agressor, tal como manisfesto nos exemplos de Morgoth, Sauron e Saruman. Contudo, o direito de resistência, mesmo por intermédio do uso da força, é algo necessário para a preservação da liberdade, o que faz Tolkien rejeitar como ingênua a visão pacifista, tal como expresso em diferentes partes de sua correspondência, com destaque para uma carta, escrita em 25 de abril de 1954, na qual, ao tratar da enigmática figura de Tom Bombadil e seu papel na narrativa, afirmou:

[...] A história é disposta em termos de um lado bom e um lado mau, beleza contra feiúra impiedosa, tirania contra majestade, liberdade moderada com consentimento contra compulsão que há muito tempo perdera qualquer objetivo que não o mero poder, $\mathrm{e}$ assim por diante; mas ambos os lados em certo grau, conservador ou destrutivo, querem uma medida de controle. Mas se você tiver, por assim dizer, feito um "voto de pobreza", renunciando ao controle e contentar-se com as coisas em si mesmas sem referência a si próprio, vigiando, observando e de certa forma conhecendo, então a questão dos bens e males do poder e do controle pode tornar-se totalmente sem sentido para você, e os meios do poder sem valor algum. É uma visão pacifista natural, que sempre vem à mente quando há uma guerra. Porém, a visão de Valfenda parece ser a de que algo

\footnotetext{
${ }^{165}$ Idem. As Cartas de J. R. R. Tolkien. p. 227-28.
}

excelente de se ter representado, mas que de fato há coisas com as quais não pode lidar e que, no entanto, sua existência depende delas. Em última instância, apenas a vitória do Oeste permitirá Bombadil a continuar, ou mesmo a sobreviver. Nada lhe restaria no mundo se Sauron. [...] $]^{166}$.

Nessa grande luta entre os partidários da preservação da liberdade individual e os agressores em busca da ampliação do poder arbitrário é possível se delinear uma série de elementos relacionados à chamada liberdade política ou liberdade coletiva, que se manifesta em formas distintas ao longo de diferentes passagens de $O$ Senhor dos Anéis. O aspecto fundamental dessa liberdade política é a própria existência de diferentes organizações comunitárias como, por exemplo, o Condado dos Hobbits, os reinos humanos de Gondor e dos cavaleiros de Rohan, as sociedades dos Ananos ou dos Ents, e as comunidades éficas de Valfenda e de Lothlórien. Nessa perspectiva, o objetivo político de Sauron pode ser vista como uma tentativa de criação de um governo mundial, no qual ele próprio seria o Rei-Deus, numa luta tirânica contra a autonomia local das diferentes comunidades. Outro fator importante dessa liberdade política em O Senhor dos Anéis é a busca por decisões consensuais por intermédio do livre debate e deliberações democráticas fundada na participação dos que irão se envolver na ação; tal como, dentre tantos outros, nos casos do Conselho de Elrond, no qual cada um dos participantes relatou os indícios do avanço das forças de Mordor, foram revelados para os presentes os planos de Sauron e a traição de Saruman, e se debateu qual destino deveria ser dado ao Um Anel ${ }^{167}$; o Entebate, a longa assembléia dos Ents no qual as criaturas arvorescas decidiram lutar contra as forças de Saruman apoiando a causa dos outros povos livres $^{168}$; e o chamado Último Debate, realiza-

\footnotetext{
${ }^{166}$ Ibidem. p. 173.

${ }^{167}$ Idem. A Sociedade do Anel. p. 253-87.

${ }^{168}$ Idem. As Duas Torres. p. 75-89.
} 
do após a vitória contra as forças de Sauron na Batalha dos Campos do Pelennor, no qual se deliberou que os exércitos do Oeste marchariam rumo ao Portão Negro de Mordor, aumentando, assim, as chances do Portador do Anel cumprir a demanda de destruir o objeto na Montanha da Perdição, ao desviar o olhar de Sauron ${ }^{169}$.

O recorrente uso em O Senhor dos Anéis de processos democráticos não deve ser tomado, no entanto, como uma aceitação do democratismo ou do igualitarismo por parte de Tolkien, mas, apenas, como uma demonstração de que na luta contra o Poder aqueles que estão defendendo a Causa do bem não devem adotar os mesmos critérios arbitrários do Inimigo, impondo, mesmo que para um fim correto, a própria vontade. O modelo de democracia apresentado na saga tolkieniana difere em muito da abstrata e despersonalizada forma moderna adotada pela maioria das sociedades ocidentais, sendo um mero meio de promoção da liberdade individual e da autonomia das comunidades locais, tais como expressos no princípio católico da subsidiariedade, que será abordado mais adiante. No rascunho de uma carta, escrita em abril de 1956, Tolkien ressaltou sua posição com as seguintes palavras:

[...] Não creio que mesmo o Poder ou a Dominação sejam o verdadeiro centro de minha história. Isso fornece o tema de uma guerra, sobre alguma coisa suficientemente sombria e ameaçadora para parecer-se naquele momento de suprema importância, mas é principalmente "um cenário" para as personagens mostrarem-se. $\mathrm{O}$ verdadeiro tema para mim é sobre algo muito mais permanente e difícil: Morte e Imortalidade - o mistério do amor pelo mundo nos corações de uma raça "fadada" a deixá-lo e aparentemente perdê-lo; a angústia de uma raça "fadada" a não deixá-lo até que toda a história deste mundo estimulada pelo mal esteja completa. [...]. Não sou um "democrata" apenas porque a "humildade" e a igualdade são princípios espirituais corrompidos pela

${ }^{169}$ Idem. O Retorno do Rei. p. 141-52. tentativa de mecanizar e formalizá-los, com o resultado de que conseguimos não pequenez e humildade universais, mas grandeza e orgulho universais, até que algum Orc apodere-se de um anel de poder - e então recebemos servidão. $[\ldots]^{170}$.

Tanto na perspectiva tolkieniana quanto para os pensadores da Escola Austríaca a liberdade coletiva não é um fim em si mesmo, mas um simples meio, que em alguns casos, mas não em todos, pode servir ao propósito de preservação da liberdade individual. $O$ fundamento último para a defesa da autonomia pessoal contra os abusos do poder é a defesa do verdadeiro individualismo, definido por Mises do seguinte modo:

A filosofia comumente denominada individualismo é uma filosofia de cooperação social e de intensificação progressiva dos vínculos sociais. Por outro lado, a aplicação das ideias coletivistas só pode resultar na desintegração social e na luta armada permanente. É claro que todas as variedades de coletivismo prometem a paz eterna a partir do dia de sua vitória final e da derrota completa de todas as outras ideologias e seus defensores. Entretanto, para que estes planos sejam realizados, é necessária uma mudança radical no gênero humano. Os homens devem ser divididos em duas classes: de um lado, o ditador onipotente, quase divino, e, do outro, as massas, que devem abdicar da vontade e do raciocínio próprio para se tornarem meros peões no tabuleiro do ditador. As massas devem ser desumanizadas, para que se possa fazer de um homem o seu senhor divinizado. Pensar e agir, as características primordiais do homem, tornar-se-iam o privilégio de um só homem ${ }^{171}$.

Não devemos confundir o conceito de individualismo adotado pelos pensadores da Escola Austríaca com a defesa simplista do atomismo social ou com o vício do egoísmo. De acordo com a análise de Hayek, a verdadeira concepção de individualismo não deve

\footnotetext{
${ }^{170}$ Idem. As Cartas de J. R. R. Tolkien. p. 236.

${ }^{171}$ MISES. Ação Humana. p. 192.
} 
ser oposta às noções de vida comunitária e de cooperação social, pois é herdeira do pensamento liberal clássico, particularmente, das análises de Edmund Burke sobre a temática ${ }^{172}$. $\mathrm{O}$ verdadeiro igualitarismo amplia a cooperação social, ao passo que o coletivismo e o igualitarismo reduzem os vínculos sociais, ao criar um ambiente propício à implantação do "despotismo democrático", definido por Alexis de Tocqueville (1805-1859) com as seguintes palavras:

Não creio, pois, que a espécie de opressão pela qual os povos democráticos se acham ameaçados se assemelhe a algo que a precedeu no mundo; nossos contemporâneos não poderiam encontrar na lembrança a sua imagem. Em vão procuro uma expressão que reproduza exatamente a ideia que tenho e que a encerre; as antigas palavras, despotismo e tirania, não convêm de maneira alguma. $\mathrm{O}$ fenômeno é novo; é preciso, pois, defini-lo, já que não posso dar-lhe um nome. Procuro descobrir sob que traços novos o despotismo poderia ser produzido no mundo: vejo uma multidão inumerável de homens semelhantes e iguais, que sem descanso se voltam sobre si mesmos à procura de pequenos e vulgares prazeres, com os quais enchem a alma. Cada um deles, afastado dos demais, é como um estranho ao destino de todos os outros: seus filhos e seus amigos particulares para ele constituem toda a espécie humana; quanto ao restante dos seus concidadãos, está ao lado deles, mas não os vê; toca-os e não os sente; existe apenas em si e para si mesmo, e, se ainda lhe resta uma família, pode-se ao menos dizer que não tem pátria.

Acima destes, eleva-se um poder imenso e tutelar, que se encarrega sozinho de garantir o seu prazer e velar sobre sua sorte. É absoluto, minucioso, regular, previdente e brando. Lembraria o mesmo pátrio poder, se, como este, tivesse por objeto preparar os homens para idade viril; mas ao contrário, só procura fixá-los irrevogavelmente na infância; agrada-lhe que os cidadãos se rejubilem,

172 HAYEK, F. A. Individualism: True and False. In: Individualism and Economic Order. Chicago: University of Chicago Press, 1948. p. 1-32. desde que não pensem senão em rejubilar-se. Trabalha de bom grado para sua felicidade, mas deseja ser o seu único agente e árbitro exclusivo; provê e assegura as suas necessidades, facilita os seus prazeres, conduz os seus principais negócios, dirige a sua indústria, regula as suas sucessões, divide as suas heranças; que lhe falta tirar-lhes inteiramente, senão o incômodo de pensar e a angústia de viver?

É assim que, todos os dias, torna menos útil e mais raro o emprego do livre arbítrio; é assim que encerra a ação da vontade num pequeno espaço e, pouco a pouco, tira de cada cidadão até o emprego de si mesmo. A igualdade preparou os homens para todas essas coisas, dispondo-os a sofrer e muitas vezes até a considerá-las como um benefício ${ }^{173}$.

A "ditadura da maioria" foi instaurada ou ampliada pelo "despotismo democrático" em todas as sociedades ocidentais no período posterior à Segunda Guerra Mundial, sendo a própria raiz dos nacionalismos responsáveis pelo conflito bélico. Em nossos dias, tal caminho de servidão é ampliado pela "ditadura das minorias", que tem, gradativamente, aumentando as tensões internas nos países democráticos, numa "luta" pelos recursos públicos ou proteções especiais oferecidos pela máquina estatal. Ao longo do século XX, o crescimento do "Estado de Bem-Estar Social" ou "Estado Provedor", operante em todas as sociedades democráticas, ampliou dramaticamente o controle do governo sobre a sociedade, reduzindo drasticamente a liberdade individual e concentrando poder nas mãos dos que "gostam de se meter na vida dos outros, e falar arrotando importância"174.

De acordo com o próprio Tolkien, uma "parte essencial do enredo"175 da saga O Senhor dos Anéis é o oitavo capítulo do livro VI de O Retorno do Rei, narrando “O expurgo do

173 TOCQUEVILLE, Alexis de. A Democracia na América. Pref. Antônio Paim; Trad. e notas de Neil Ribeiro da Silva. Belo Horizonte: Editora Itatiaia, 1987. Livro II, Quarta Parte, Capítulo VI, p. 531-32.

${ }^{174}$ TOLKIEN. O Retorno do Rei. p. 284.

${ }^{175}$ Idem. A Sociedade do Anel. p. xiv. 
Condado"176, que, infelizmente, não foi incluído na trilogia de filmes de Peter Jackson. O capítulo relata a luta de Frodo, Sam, Pippin e Merry, após retornarem da Guerra do Anel, para libertar o Condado do "regime fascista" implantado por Saruman e seus rufiões. Nas palavras do autor, a passagem, como tantas outras da narrativa, não possui "qualquer significado alegórico ou referência política de qualquer tipo"177. O episódio serve, acima de tudo, para ressaltar um aspecto fundamental da estrutura narrativa, "planejada pare ser 'hobbitocêntrica', isto é, primeiramente um estudo do enobrecimento (ou santificação) dos humildes" ${ }^{\prime 178}$.

A organização política e econômica do Condado assemelha-se em muitos aspectos ao modelo de sociedades distributistas, concebido por G. K. Chesterton e Hilaire Belloc (1870-1953) e outros pensadores católicos ${ }^{179} \mathrm{a}$ partir dos princípios da Doutrina Social da Igreja, sistematizado, originalmente, na encíclica Rerum Novarum, promulgada pelo papa Leão XIII em 15 de maio de 1891. O ponto mais importante defendido pelo Distributismo é o princípio católico da subsidiariedade, que na encíclica Quadragesimo Anno, promulgada pelo papa Pio XI em 15 de maio de 1931, é formulado nos seguintes termos:

${ }^{176}$ Idem. O Retorno do Rei. p. 279-303. Ver, também: PLANK, Robert. The Scouring of the Shire: Tolkien's View of Facism. In: LOBDELL, Jared (Ed.). A Tolkien Compass. Chicago: Open Court, 2003. p. 105-13.

177 TOLKIEN. A Sociedade do Anel. p. xiv.

${ }^{178}$ Idem. As Cartas de J. R. R. Tolkien. p. 228.

${ }^{179}$ Os principais livros de Belloc e de Chesterton sobre a filosofia social do Distributismo foram publicados, originalmente, em 1912,1926 1936, estando disponíveis atualmente nas respectivas edições: BELLOC, Hilaire. The Servile State. Intr. Robert Nisbet. Indianapolis: Liberty Fund, 1977; CHESTERTON, G. K. The Outline of Sanity. In: The Collected Works of G. K. Chesterton: Volume V. Intr. Michael Novak; Posf. Edward S. Shapiro. San Francisco: Ignatius Press, 1987. p. 15221. BELLOC, Hilaire. An Essay on the Restoration of Property. Intr. John Sharpe. Norfolk: IHS Press, 2009. Para uma crítica ao Distributismo de um ponto de vista, ao mesmo tempo, católico e libertário, ver: WOODS JR., Thomas. Beyond Distributism. Grand Rapids: Acton Institute, 2008.
[...] assim como é injusto subtrair aos indivíduos o que eles podem efetuar com a própria iniciativa e capacidade, para o confiar à coletividade, do mesmo modo passar para uma sociedade maior e mais elevada o que sociedades menores e inferiores podiam conseguir, é uma injustiça, um grave dano e perturbação da boa ordem social. O fim natural da sociedade e da sua ação é coadjuvar os seus membros, não destruí-los nem absorvê-los $(Q A \S 79)^{180}$.

As similitudes entre a filosofia social tolkieniana e alguns dos princípios basilares do Distributismo foi ressaltado por inúmeros analistas de $O$ Senhor dos Anéis, como por exemplo, os já citados Bradley Birzer ${ }^{181}$, Stratford Caldecott ${ }^{182}$, Peter Kreeft ${ }^{183}$ e Joseph Pearce $^{184}$. O próprio Tolkien descreve a organização do Condado, no prólogo de $A$ Sociedade do Anel, do seguinte modo:

[...] Nessa época o Condado mal tinha um "governo". Na maioria das vezes as famílias cuidavam de seus próprios negócios. Cultivar comida e comê-la ocupava a maior parte de seu tempo. Em outros assuntos eles eram, em geral, generosos e não gananciosos, mas satisfeitos e moderados, de modo que terras, fazendas, oficinas e pequenos comércios tendiam a permanecer inalterados por gerações.

Permanecia, é claro, a antiga tradição, acerca do Rei de Fornost [...]. Mas não tinha havido um rei por mais de mil anos [...]. Mas os hobbits ainda comentavam sobre povos selvagens e coisas perversas (como trolls) que não tinham ouvido falar do rei. Pois eles atribuíam ao rei de outrora todas as suas re-

${ }^{180}$ Utilizamos aqui a seguinte edição do documento: Carta Encíclica Quadragesimo Anno: Sobre a Restauração e Aperfeiçoamento da Ordem Social em Conformidade com a Lei Evangélica. Trad. Tipografia Poliglota Vaticana. Rio de Janeiro: Paulinas, $4^{\underline{a}}$ Ed., 2001.

${ }^{181}$ BIRZER. J. R. R. Tolkien's Sanctifying Myth. p. 109-26.

${ }^{182}$ CALDECOTT. The Power of the Ring. p. 156-59.

${ }^{183}$ KREEFT. The Philosophy of Tolkien. p. 163-72.

${ }^{184}$ PEARCE. Tolkien, Man and Myth. p. 153-81. 
gras essenciais; e geralmente mantinham as leis do livre-arbítrio, pois estas eram As Regras (como diziam), tão antigas quanto justas.

É verdade que a família Tûk tinha se destacado havia muito tempo, pois o ofício de Thain tinha passado para eles [...]. O Thain era o mestre do Tribunal do Condado, e capitão das tropas do Condado e dos Hobbits-em-armas, mas como tribunais e exércitos só eram organizados em tempos de emergência, que não ocorriam mais, o título de Thain não era agora mais que uma honraria. [...]

O único cargo oficial no Condado nessa época era o de Prefeito de Grã Cava (e do Condado), que era eleito a cada sete anos [...]. Como Prefeito, seu quase único dever era presidir banquetes, oferecidos nos feriados do Condado, que ocorriam a intervalos frequentes. Mas os cargos de Agente Postal e de Primeiro Condestável foram acrescentados ao de Prefeito, de modo que este gerenciava tanto o Serviço de Mensagens como a Patrulha. Esses eram os únicos funcionários do Condado, e os Mensageiros eram os mais numerosos e os mais ocupados dos dois. [...] "Condestáveis" foi o nome que os hobbits deram à sua polícia, ou ao seu equivalente mais próximo. Eles não tinham, obviamente, uniformes e na prática estavam mais para pastores que para policiais, mais envolvidos com animais perdidos que com pessoas. Havia apenas doze deles em todo o Condado $[\ldots]^{185}$.

Adotando o título de "O Chefe", Saruman dominou o Condado com o apoio de rufiões, implantando uma forma autoritária de governo central que representou uma completa mudança no modo de vida dos Hobbits. O "sarumanismo" se caracterizou pela adoção de uma longa lista de regras discricionárias contrárias aos costumes livres do Condado. Dentre tais regulações se destacam as proibições da entrada no Condado entre o pôr-do-sol e a aurora, a de acolher pessoas de improviso e a de consumir cerveja ou erva-de-fumo; a realização de coleta, estocagem

\footnotetext{
185 TOLKIEN. A Sociedade do Anel. p. 10-11.
}

e redistribuição da produção de alimentos por funcionários públicos; o fechamento das estalagens e tavernas; a criação de quotas de consumo diário de comida e de lenha; a ampliação maciça, contra a vontade dos hobbits, do número de Condestáveis, que, por sua vez, não tinham mais autorização para abandonar a função; a implantação da censura e o estimulo às delações; o encarceramento arbitrário de hobbits; o confisco e a destruição de propriedades privadas; além do corte das árvores e da poluição do rio e do ar por maquinarias. A preservação do modo de vida da população do Condado só foi possível por meio de uma violenta batalha contra o domínio dos rufiões e pela liberdade, que foi comandada por Merry, Pippin e Sam, na qual Frodo participou, "mas sem sacar a espa$d a$ ", exercendo apenas a tarefa de "impedir que os hobbits, em sua ira pela perda dos entes queridos, matassem aqueles inimigos que tinham deposto as armas" 186 .

O modo de vida dos Hobbits e a organização política e econômica do Condado, no entanto, "não são uma visão utópica ou recomendados como um ideal em sua própria era ou em qualquer outra", pois, ao possuir o mesmo entendimento adotado pela tradição conservadora, de Edmund Burke a Russell Kirk, sobre as diferentes experiências culturais, Tolkien compreende que, "como todos os povos", os hobbits "são um acidente histórico"187, não havendo, assim, qualquer forma de determinismo capaz de apresentar um modelo ideal de vida comunitária válida para diferentes contextos. O que está em questão tanto na demanda para destruir o Um Anel quanto na defesa do modo de vida do Condado, autoritariamente modificado pela ideologia do "sarumanismo", não é um projeto político, mas um dever humano. $\mathrm{O}$ próprio Tolkien ressaltou esse aspecto com as seguintes palavras:

Não gosto do uso de "político" em tal contexto; parece-me falso. Parece-me claro que

\footnotetext{
${ }^{186}$ Idem. O Retorno do Rei. p. 298.

${ }^{187}$ Idem. As Cartas de J. R. R. Tolkien. p. 190.
} 
o dever de Frodo era "humano", não político. Ele naturalmente pensou primeiro no Condado, uma vez que suas raízes estavam lá, mas a busca tinha como seu objetivo não preservação deste ou daquele regime, tal como a parte república, parte aristocracia do Condado, mas a libertação de uma tirania maligna de todos os "humanos" - incluindo aqueles, tais como os "orientais" e os Haradrim, que ainda eram servos da tirania.

Denethor foi maculado por mera política: daí seu fracasso e sua desconfiança em Faramir. Tornara-se para ele um motivo primário preservar o regime de Gondor, tal como era, contra outro potentado, que tornara a si mesmo mais forte e deveria ter temido e oposto por essa razão do que por ele ser cruel e malévolo. Denethor desprezava homens inferiores, e pode-se ter certeza de que não fazia distinção entre orcs e aliados de Mordor. Se tivesse sobrevivido como vencedor, mesmo sem o uso do Anel, ele teria dado um longo passo para tornar-se um tirano, e os termos e o tratamento que ele daria aos povos iludidos do leste e do sul teria sido cruéis e vingativos. Tornara-se um líder "político": isto é, Gondor contra o resto. Essa, porém, não foi a política ou a obrigação estabelecida pelo Conselho de Elrond. Somente depois de ouvir o debate e perceber a natureza da busca Frodo aceitou o fardo de sua missão. De fato, os Elfos destruíram seu próprio regime em busca de uma obrigação "humana". Isso não ocorreu meramente como um dano desafortunado da Guerra; era do conhecimento deles ser um resultado inevitável da vitória, que de modo algum poderia ser vantajoso para os Elfos. Não se pode dizer que Elrond tenha uma obrigação ou propósito político ${ }^{188}$.

\section{Conclusão}

A narrativa de $O$ Senhor dos Anéis, como explicitada no presente ensaio, não deve ser entendida como uma alegoria da fé católica professada pelo autor ou do contexto dos acontecimentos históricos da Segunda Guerra Mundial. Mesmo abominando o regime nacio-

\footnotetext{
${ }^{188}$ Ibidem. p. 231
}

nal-socialista de Adolf Hitler (1889-1945) ou qualquer outra forma de tirania, J. R. R. Tolkien não era um homem ingênuo para aceitar a propaganda governamental britânica e acreditar que os Aliados eram heróis lutando pela liberdade da humanidade contra a verdadeira encarnação do mal representada pelos nazistas, tal como nas batalhas dos protagonistas de sua saga contra as forças de Sauron. De modo semelhante ao de F. A. Hayek, no livro O Caminho da Servidão, no qual alertou sobre a forma como a ampliação das funções do governo e o crescimento do planejamento estatal durante a Segunda Guerra Mundial levaria, necessariamente, à redução das liberdades individuais nas democracias ocidentais ${ }^{189}$, Tolkien via nos esforços externos de guerra dos Aliados contra o Eixo um grande risco para a liberdade por conta da expansão substancial da esfera de atuação do poder estatal. Em uma carta para seu filho Christopher Tolkien, escrita entre 23 e 25 de setembro de 1944, o posicionamento tolkieniano sobre o problema é expresso com as seguintes palavras:

Não voltei para casa até meia-noite, e caminhei com C. W. [Charles Williams] parte do caminho, quando nossa conversa se voltou para as dificuldades de se descobrir que fatores comuns, caso houvesse algum, existiam nas noções associadas com a liberdade, tal como usada atualmente. Não creio que haja alguma, pois a palavra tem sido usada de forma tão abusiva pela propaganda que ela deixou de ter qualquer valor para a razão e se tornou uma mera dose emocional para gerar calor. No máximo, ela parece implicar que aqueles que o oprimem devem falar (nativamente) o mesmo idioma - o que, em último caso, é tudo que as ideias confusas de raça ou nação se resumem; ou de classe na Inglaterra, por falar nisso... As notícias da guerra ocidental, é claro, ocupam boa parte de nossas mentes, mas você sabe sobre elas tanto quanto nós. Tempos ansiosos, apesar da gritaria um tanto prematura. [...] Mas é angustiante ver a imprensa se rebaixando a um nível tão baixo [...]. Sabíamos que Hitler era um cafajestinho vulgar e ignorante, [...];

${ }^{189}$ HAYEK. O Caminho da Servidão. p. 173-90. 
mas parece haver muitos cafajestinhos vulgares e ignorantes que não falam alemão e que dada a mesma oportunidade, apresentariam a maioria das características hitlerianas [...], eles são cascavéis e não sabem a diferença entre o bem e o mal! [...] Você não pode enfrentar o Inimigo com o Anel dele sem se tornar o Inimigo $[. . .]^{190}$.

O autor de O Senhor dos Anéis, estava extremamente preocupado com a interferência governamental na vida dos indivíduos, contudo a visão tolkieniana sobre a realidade dificilmente pode ser classificada de acordo com as modernas correntes políticas contemporâneas, pois, em muitos aspectos, era, ao mesmo tempo, um pré-moderno e um pós-moderno em suas visões nostálgicas sobre natureza, espiritualidade, ética, sociedade, política, cultura, literatura e fantasia ${ }^{191}$. Ao escrever para o filho Christopher, numa carta datada de 9 de novembro de 1943, quando o jovem estava em treinamento militar da R.A.F. em Manchester, Tolkien afirmou:

[...] Nascemos em uma era sombria fora do tempo devido (para nós). Porém, há este consolo: de outro modo não saberíamos, ou muito menos amaríamos, o que amamos. Imagino que o peixe fora d'água é o único a ter uma noção da água. Também temos ainda pequenas palavras para usar. "Eu não me curvo à Coroa de Ferro, nem meu cetrozinho dourado enterro". Enfrente os Orcs, com palavras aladas, hildenǽddran (víboras-de-guerra), dardos mordentes - mas tenha certeza do alvo antes de atirar ${ }^{192}$.

Os tiranos, na percepção de Tolkien, "perdem de vista objetivos", por conta de um fator moral ou patológico, "tornam-se crúeis e gostam de esmagar, ferir e macular" ${ }^{\prime 193}$. Escrevendo para Christopher, em 30 de janeiro de

\footnotetext{
${ }^{190}$ TOLKIEN. As Cartas de J. R. R. Tolkien. p. 94-95.

${ }^{191}$ Sobre a temática, ver: CURRY, Patrick. Defending Middle-Earth - Tolkien: Myth and Modernity. Boston: Houghton Mifflin Company, 2004.

192 TOLKIEN. As Cartas de J. R. R. Tolkien. p. 67.

${ }^{193}$ Ibidem. p. 193.
}

1945, ressalta o exemplo dos santos que nunca curvaram "seus corações e vontades ao mundo ou ao espírito maligno", males encarnados na modernidade pelo "socialismo em cada uma de suas facções em guerra atualmente"194. Em 1956, Tolkien afirmou:

[...] Não sou um "socialista" em qualquer sentido, sendo avesso ao "planejamento" (como deve estar claro) principalmente porque os "planejadores", quando adquirem poder, tornam-se tão maus - mas eu não diria que temos que sofrer a malícia de Charcote [Saruman] e de seus Rufiões aqui, apesar do espírito de "Isengard", se não de Mordor, certamente estar aparecendo. $[. . .]^{195}$.

Diante das notícias da Conferência de Teerã, realizada entre 28 de novembro e $1^{\circ}$ de dezembro, com a participação de Winston Churchill (1874-1965), Franklin Delano Roosevelt (1882-1945) e Josef Stalin (1878-1953) para definir os rumos de ação durante a Segunda Guerra Mundial e propor acordos sobre os destino do cenário internacional após o conflito, Tolkien escreveu para o filho, numa carta datada de 9 de dezembro do mesmo ano, afirmando:

[...] Embora eu deva admitir que dei um tipo de sorriso doentio e "quase rolei no chão e já não mais me interessavam as boas maneiras" quando ouvi aquele velho assassino sedento de sangue do Josef Stalin convidar a todas as nações a se juntarem a uma família feliz de pessoas dedicadas à abolição da tirania e da intolerância! Mas também devo admitir que, na foto, nosso pequeno querubim W. S. C. [Winston Churchill] de fato $p a-$ recia o maior dos rufiões presentes. Hunf, bem! Fico pensando (se sobrevivermos a essa guerra) se restará algum lugar adequado, mesmo tolerância, para reacionários antiquados como eu (e você). Quanto maiores ficam as coisas, menos e mais estúpida ou insípida a Terra se torna. Ela se tornará um maldito suburbiozinho provinciano. $[\ldots]^{196}$.

\footnotetext{
${ }^{194}$ Ibidem. p. 110.

195 Ibidem. p. 266.

${ }^{196}$ Ibidem. p. 67.
} 
O completo desapontamendo do autor de O Senhor dos Anéis com a Segunda Guerra Mundial, bem como os piores presságios sobre os rumos da política internacional, que começava a dar sinais de tender em direção à expansão da esfera de influência da Rússia Soviética e ao início das rivalidades entre essa potência e os Estados Unidos, dando origem à Guerra Fria, é expresso numa carta para Christopher, datada de 29 de maio de 1945, na qual afirma:

Pelo menos seria um certo consolo para mim se você escapasse da R.A.F. E eu espero, caso a transferência [para a Armada Aérea Ligeira] seja efetuada, que isso signifique uma transferência verdadeira e uma recomissão. Não seria fácil para mim expressar a você o tamanho de minha aversão pelo Terceiro Serviço [Força Aérea] - que, entretanto, pode ser, e é para mim, combinada com admiração, gratidão e, acima de tudo, piedade pelos jovens pegos nele. Mas é o avião de guerra o verdadeiro vilão. E nada pode realmente reparar meu pesar por você, meu mais amado, ter qualquer ligação com ele. Meus sentimentos são mais ou menos aqueles que Frodo teria tido se descobrisse alguns Hobbits aprendendo a montar aves Nazgûl "para libertar o Conda$\mathrm{do}^{\prime \prime}$. Embora neste caso, como nada conheço do imperialismo britânico ou americano no Extremo Oriente que não me encha de arrependimento e náusea, receio que eu não seja sequer apoiado por um vislumbre de patriotismo no que resta desta guerra. Eu não daria um penny a ela, o que dirá um filho, fosse eu um homem livre. Ela só pode beneficiar os Estados Unidos ou a Rússia, provavelmente a última. Mas, pelo menos, a Guerra Russa-Americana ainda não eclodirá por um ano ${ }^{197}$.

Mesmo tendendo mais para a forma de pensamento conservador tradicionalista defendida por Russell Kirk, no que tange à importância da tradição, da cultura e da moral como fundamento da liberdade, as opiniões políticas de Tolkien tangenciavam, tam-

${ }^{197}$ Ibidem. p. 115. bém, em vários aspectos a crítica libertária de Ludwig von Mises e de Murray Rothbard aos abusos do poder estatal. Na já citada carta de 9 de novembro de 1943 para o filho, Tolkien afirmou:

Minhas opiniões políticas tendem cada vez mais para o anarquismo (filosoficamente compreendido como significando a abolição do controle, não homens barbados com bombas) - ou para a monarquia "inconstitucional". Eu prenderia qualquer um que use a palavra Estado (em qualquer outro sentido que não o do reino inanimado da Inglaterra e seus habitantes, uma coisa que não tem poder, direitos nem uma mente); e, após uma chance de retratação, executaria todos que se permanecessem obstinados! Seria muito melhor se pudéssemos voltar aos nomes pessoais. Governo é um substantivo abstrato que significa a arte e o processo de governar, e deveria ser uma ofensa escrevê-lo com um G maiúsculo ou usá-lo para se referir as pessoas. [...] Em todo caso, o estudo apropriado do Homem é tudo, menos o Homem; e o trabalho mais impróprio a qualquer homem, mesmo os santos (os quais, de qualquer maneira, ao menos relutavam em realizá-lo), é mandar em outros homens. Nem mesmo um homem em um milhão é adequado para tal, e menos ainda aqueles que buscam a oportunidade. $\mathrm{E}$ pelo menos isso é feito apenas a um pequeno grupo de homens que sabem quem é seu mestre. [...] Mas o horror particular do mundo atual é que toda a maldita coisa está num mesmo saco. $[\ldots]^{198}$.

O profundo compromisso de Tolkien com a fé católica foi o alicerce espiritual tanto de uma firme postura moral diante dos mais graves problemas de sua época quanto da Perspectiva Criacionista e da Perspectiva Ética que se manifestam em toda a narratologia da saga O Senhor dos Anéis. Nesse contexto, há na subcriação tolkieniana uma relação necessária entre preservação da tradição, aceitação das mudanças inerentes à dinâmica histórica, defesa da liberdade individual contra o arbítrio do poder, exaltação da criativi-

\footnotetext{
${ }^{198}$ Ibidem. p. 66-67.
} 
dade, e luta contra a massificação que destrói a singularidade individual de cada criatura. Diante de todas essas características os escritos de Tolkien não podem ser vistos como negação tanto da postura reacionária contrária a qualquer mudança, tal como assumida por Denethor, quanto da atitude revolucionário, expressa no projeto progressista de Saruman. Além de esclarecer a correta dinâmica entre permanências e mudanças, em uma carta, datada de 25 de setembro de 1954, Tolkien rechaça as visões simplificadoras de alguns críticos sobre a luta entre o bem e o mal em $O$ Senhor dos Anéis com a seguinte afirmação:

[...] Não sou um reformador nem um "embalsamador"! Não sou um "reformador" (por exercício de poder) posto que isso parece estar condenado ao sarumanismo. Mas a "embalsamação" possui suas próprias punições.

Alguns críticos chamaram a coisa toda de simplória, apenas uma simples luta entre o Bem e o Mal, com todos os bons apenas bons e os maus apenas maus. Perdoável, talvez (embora pelo menos Boromir tenha sido negligenciado), em pessoas com pressa e com apenas um fragmento para ler e, é claro, sem as primeiras escritas, mas não publicadas histórias Élficas. Mas os Elfos não são totalmente bons ou têm razão. Não tanto por terem flertado com Sauron, já que com ou sem sua assistência eles eram "embalsamadores". Queriam fazer uma omelete sem quebrar alguns ovos: viver na Terra-média histórica e mortal porque se afeiçoaram a ela (e talvez porque lá possuíam as vantagens de uma casta superior), e assim tentaram deter a mudança e a história desta, deter seu crescimento, mantê-la como um santuário, mesmo que em grande parte fosse um deserto, onde poderiam ser "artistas" - e ficaram sobrecarregados pela tristeza e pelo arrependimento nostálgico. A seu modo, os Homens de Gondor eram similares: um povo a definhar, cujos únicos "locais sagrados" eram seus túmulos. Mas de qualquer maneira, esta é uma história sobre uma guerra, e se a guerra é permitida (ao menos como um tópico e um cenário), não é muito bom reclamar de que todas as pessoas de um lado estejam contra as do outro.
Não que eu tenha tornado essa questão tão simples: há Saruman, Denethor e Boromir; e há traições e brigas até mesmo entre os Orcs $[\ldots]^{199}$.

A complexidade extrema da narratologia tolkieniana é um reflexo da Perspectiva Criacionista e da Perspectiva Ética adotadas pelo autor, que fundamentam uma antropologia filosófica que ressalta a singularidade humana, constituindo a fonte principal da defesa da liberdade individual e da dignidade da pessoa contra as diferentes concepções ideológicas coletivistas que dominaram o cenário intelectual do século XX. A estrutura "hobbitocêntrica" adotada na narrativa, ao exaltar a importância da humildade do senso comum contra os projetos arrogantes dos planejadores, pode ser utilizada de modo apropriado para explicar simbolicamente tanto o princípio da Prudência, adotado, desde Edmund Burke até Russell Kirk, como principal virtude política pela moderna tradição conservadora, quando a noção de Incerteza ou Falibilidade na já citada tríade básica que constitui, junto com as noções de Ação Humana e Tempo Dinâmico, o núcleo fundamental do pensamento da Escola Austríaca.

De modo semelhante ao fato de que "estudar a Escola Austríaca é fundamental para entender as mazelas de nossa época, e descobrir soluções, pautadas no bom senso, para os erros criados pela intervenção estatal na vida econômica"200, é possível afirmar que a leitura de O Senhor dos Anéis é, provavelmente, o meio mais eficaz para despertar a imaginação moral dos defensores da liberdade no momento histórico em que vivemos. Além de ser dotada de uma beleza estilística única e de possuir uma narrativa envolvente, a saga tolkieniana, de forma simbólica, alerta para os riscos inerentes do entendimento errôneo da liberdade enquanto poder, da busca gananciosa pela posse do poder, da falsa crença tribalista manifesta no racismo ou no nacionalismo, da ob-

\footnotetext{
${ }^{199}$ Ibidem. p. 190.

${ }^{200}$ CATHARINO. A Economia do Bom Senso. p. 38.
} 
sessão comodista pela segurança, da adoção do progressismo massificante ou do embalsamamento paralisador, da confiança essessiva no planejamento, e da idolátrica deificação das burocráticas estruturas governamentais, males que se tornaram na modernidade as principais ameaças ao desenvolvimento livre e criativo das potencialidades humanas. Diferente de certas obras panfletárias que de- liberadamente tentam doutrinar a audiência, os escritos de Tolkien têm como preocupação primordial contar uma boa estória e ao rejeitar o didatismo das alegorias respeitam a liberdade do leitor, que por conta própria poderá ou não utilizar tais criações como uma das armas na luta em defesa da verdade, da liberdade e da justiça. cos 